University of Nebraska - Lincoln

DigitalCommons@University of Nebraska - Lincoln

Faculty Publications in the Biological Sciences

Papers in the Biological Sciences

2006

\title{
Anaerobic redox cycling of iron by freshwater sediment microorganisms
}

Karrie A. Weber

University of Nebraska-Lincoln, kweber@unl.edu

Matilde M. Urrutia

University of Alabama - Tuscaloosa

Perry F. Churchill

University of Alabama - Tuscaloosa

Ravi K. Kukkadapu

Pacific Northwest National Laboratory, Richland, WA

Eric E. Roden

University of Alabama - Tuscaloosa, eroden@bsc.as.ua.edu

Follow this and additional works at: https://digitalcommons.unl.edu/bioscifacpub

Part of the Life Sciences Commons

Weber, Karrie A.; Urrutia, Matilde M.; Churchill, Perry F.; Kukkadapu, Ravi K.; and Roden, Eric E., "Anaerobic redox cycling of iron by freshwater sediment microorganisms" (2006). Faculty Publications in the Biological Sciences. 217.

https://digitalcommons.unl.edu/bioscifacpub/217

This Article is brought to you for free and open access by the Papers in the Biological Sciences at DigitalCommons@University of Nebraska - Lincoln. It has been accepted for inclusion in Faculty Publications in the Biological Sciences by an authorized administrator of DigitalCommons@University of Nebraska - Lincoln. 


\section{Anaerobic redox cycling of iron by freshwater sediment microorganisms}

Karrie A. Weber, ${ }^{1 * \dagger}$ Matilde M. Urrutia, ${ }^{1}$ Perry F. Churchill, ${ }^{1}$ Ravi K. Kukkadapu ${ }^{2}$ and Eric E. Roden ${ }^{1 *}$ ${ }^{1}$ The University of Alabama, Department of Biological Sciences, Tuscaloosa, AL 35487-0206, USA.

${ }^{2}$ Pacific Northwest National Laboratory, MSIN K8-96, Richland, WA 99352, USA.

\section{Summary}

The potential for microbially mediated anaerobic redox cycling of iron $(\mathrm{Fe})$ was examined in a firstgeneration enrichment culture of freshwater wetland sediment microorganisms. Most probable number enumerations revealed the presence of significant populations of $\mathrm{Fe}$ (III)-reducing (approximately $10^{8}$ cells $\mathrm{ml}^{-1}$ ) and $\mathrm{Fe}(\mathrm{II})$-oxidizing, nitrate-reducing organisms (approximately $10^{5}$ cells $\mathrm{ml}^{-1}$ ) in the freshwater sediment used to inoculate the enrichment cultures. Nitrate reduction commenced immediately following inoculation of acetate-containing (approximately $1 \mathrm{mM})$ medium with a small quantity $(1 \% \mathrm{v} / \mathrm{v})$ of wetland sediment, and resulted in the transient accumulation of $\mathrm{NO}_{2}^{-}$and production of a mixture of gaseous end-products $\left(\mathrm{N}_{2} \mathrm{O}\right.$ and $\left.\mathrm{N}_{2}\right)$ and $\mathrm{NH}_{4}{ }^{+}$. $\mathrm{Fe}$ (III) oxide (high surface area goethite) reduction took place after $\mathrm{NO}_{3}{ }^{-}$was depleted and continued until all the acetate was utilized. Addition of $\mathrm{NO}_{3}{ }^{-}$after $\mathrm{Fe}$ (III) reduction ceased resulted in the immediate oxidation of $\mathrm{Fe}$ (II) coupled to reduction of $\mathrm{NO}_{3}{ }^{-}$to $\mathrm{NH}_{4}{ }^{+}$. No significant $\mathrm{NO}_{2}{ }^{-}$accumulation was observed during nitrate-dependent $\mathrm{Fe}$ (II) oxidation. $\mathrm{No} \mathrm{Fe}$ (II) oxidation occurred in pasteurized controls. Microbial community structure in the enrichment was monitored by denaturing gradient gel electrophoresis analysis of polymerase chain reaction-amplified 16S rDNA and reverse transcription polymerase chain reactionamplified 16S rRNA, as well as by construction of $16 \mathrm{~S}$ rDNA clone libraries for four different time points during the experiment. Strong similarities in dominant members of the microbial community were observed

Received 16 December, 2004; accepted 2 May, 2005. *For correspondence. E-mail eroden@bsc.as.ua.edu; Tel. (+1) 205348 0556; Fax (+1) 2053481403 or e-mail kweber@nature.berkeley.edu; Tel. (+1) 510642 4972; Fax (+1) 510642 4995. 'Present address: University of California, Department of Plant and Microbial Biology, Berkeley, CA 94720-3102, USA. in the $\mathrm{Fe}(\mathrm{III})$ reduction and nitrate-dependent $\mathrm{Fe}$ (II) oxidation phases of the experiment, specifically the common presence of organisms closely related ( $\geq 95 \%$ sequence similarity) to the genera Geobacter and Dechloromonas. These results indicate that the wetland sediments contained organisms such as Geobacter sp. which are capable of both dissimilatory $\mathrm{Fe}$ (III) reduction and oxidation of $\mathrm{Fe}$ (II) with reduction of $\mathrm{NO}_{3}{ }^{-}$to $\mathrm{NH}_{4}{ }^{+}$. Our findings suggest that microbially catalysed nitrate-dependent $\mathrm{Fe}$ (II) oxidation has the potential to contribute to a dynamic anaerobic $\mathrm{Fe}$ redox cycle in freshwater sediments.

\section{Introduction}

Iron $(\mathrm{Fe})$-bearing minerals are abundant in soil and sedimentary environments, where they exist predominantly as solid-phase minerals containing $\mathrm{Fe}$ in the ferrous [Fe(II)] and/or ferric [ $\mathrm{Fe}(\mathrm{III})]$ oxidation state (Cornell and Schwertmann, 1996). Cycling between $\mathrm{Fe}$ (II) and Fe(III) (i.e. Fe redox cycling) can significantly affect the biogeochemistry of hydromorphic soils and sediments (VanBreemen, 1988; Stumm and Sulzberger, 1992; Davison, 1993; Roden et al., 2004). Direct microbial (enzymatic) reduction coupled to oxidation of organic carbon and $\mathrm{H}_{2}$ by dissimilatory ironreducing bacteria (DIRB) is recognized as the dominant mechanism for $\mathrm{Fe}$ (III) oxide reduction in non-sulfidogenic anaerobic soils and sediments [see Lovley $(1991 ; 2000)$ for review]. This process contributes to both natural and contaminant (hydrocarbon) organic carbon oxidation in sedimentary environments, and exerts a broad range of impacts on the behaviour of trace and contaminant metals and radionuclides (Lovley and Anderson, 2000).

When $\mathrm{Fe}(\mathrm{II})$ comes into contact with $\mathrm{O}_{2}$ or other suitable oxidants, $\mathrm{Fe}$ (II) can be re-oxidized to $\mathrm{Fe}$ (III). The dominant role of microbial catalysis in $\mathrm{Fe}$ (II) oxidation in acidic environments (e.g. acid mine drainage and acid hot springs) is well-established (Brock and Gustafson, 1972; Singer and Stumm, 1972; Johnson et al., 1993). In contrast, $\mathrm{Fe}$ (II) is subject to spontaneous chemical oxidation by dissolved $\mathrm{O}_{2}$ at circumneutral $\mathrm{pH}$ (Davison and Seed, 1983; Millero et al., 1987), and the quantitative role of microbial catalysis in $\mathrm{Fe}(\mathrm{II})$ oxidation by $\mathrm{O}_{2}$ in circumneutral aerobic environments is still a matter of debate (Emerson, 2000; Emerson and Weiss, 2004; Roden et al., 2004). A previously unrecognized potential for microbial

(C) 2005 Society for Applied Microbiology and Blackwell Publishing Ltd

This article is a U.S. government work, and is not subject to copyright in the United States. 


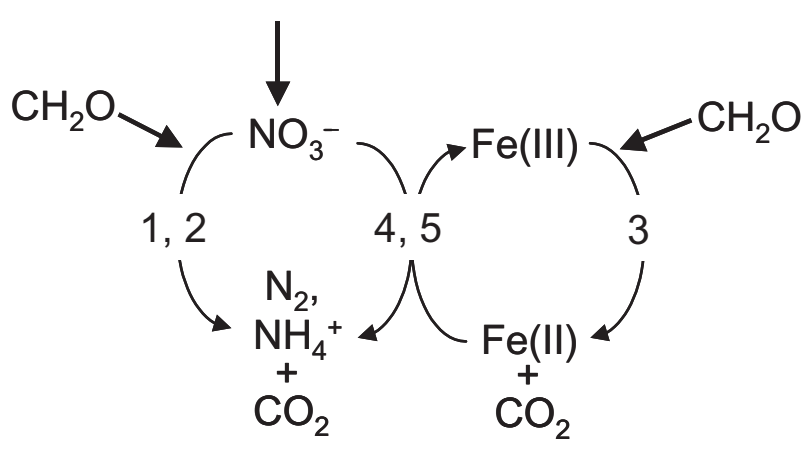

Fig. 1. Potential Fe-N redox pathways in anoxic sediments: Organotrophic $\mathrm{NO}_{3}{ }^{-}$reduction to $\mathrm{N}_{2}$ (1) or to $\mathrm{NH}_{4}^{+}$(2); organotrophic dissimilatory $\mathrm{Fe}(\mathrm{III})$ reduction (3); lithotrophic [ $\mathrm{Fe}(\mathrm{II})$-driven] $\mathrm{NO}_{3}{ }^{-}$ reduction to $\mathrm{N}_{2}$ (4) or to $\mathrm{NH}_{4}^{+}(5)$. Thick lines denote external loading of $\mathrm{NO}_{3}{ }^{-}$and organic carbon $\left(\mathrm{CH}_{2} \mathrm{O}\right)$. Temporal variations in $\mathrm{NO}_{3}{ }^{-}$and $\mathrm{CH}_{2} \mathrm{O}$ loading have the potential to cause temporal/spatial overlap of organotrophic and lithotrophic pathways (see text).

Fe redox cycling under anoxic conditions has been revealed through the recent discovery of nitrate-reducing microorganisms capable of enzymatic oxidation of $\mathrm{Fe}(\mathrm{II})$ [Straub et al. (1996; 2004); see Fig. 1]. In contrast to abiotic $\mathrm{Fe}(\mathrm{II})$ oxidation by $\mathrm{O}_{2}$, the abiotic reaction of $\mathrm{Fe}(\mathrm{II})$ with $\mathrm{NO}_{3}{ }^{-}$is negligible under the temperature and aqueous geochemical conditions typical of natural soil and sedimentary environments (Weber et al., 2001). Microorganisms capable of oxidizing $\mathrm{Fe}(\mathrm{II})$ with reduction of $\mathrm{NO}_{3}^{-}$ have been observed in several different freshwater sediments (Kluber and Conrad, 1998; Straub and BuchholzCleven, 1998; Caldwell et al., 1999; Ratering and Schnell, 2000; Chaudhuri et al., 2001; Hauck et al., 2001; Finneran et al., 2002; Senn and Hemond, 2002; Shelobolina et al., 2003) as well as sewage sludge systems (Nielsen and Nielsen, 1998a,b).

The demonstrated potential for biological nitratedependent $\mathrm{Fe}(\mathrm{II})$ oxidation in a wide variety of natural systems suggests that this reaction may play a significant role in the coupling of $\mathrm{Fe}$ and $\mathrm{N}$ redox cycles in sedimentary environments. In addition, the recent demonstration of biological nitrate-dependent $\mathrm{Fe}$ (II) oxidation by a predominant environmental Fe(III)-reducing bacterium, Geobacter metallireducens (Finneran et al., 2002), suggests that anaerobic Fe redox cycling could be catalysed by a single group of microorganisms. A tight coupling between $\mathrm{Fe}$ and $\mathrm{N}$ redox cycles in anaerobic sedimentary environments has significant implications for mechanisms of $\mathrm{NO}_{3}^{-}$ removal and the regeneration of reactive $\mathrm{Fe}(\mathrm{III})$ oxides in hydromorphic soils and sediments, as well as the transformation of various natural and contaminant organic and inorganic compounds.

Although the potential for enzymatic Fe(II) oxidation coupled to $\mathrm{NO}_{3}{ }^{-}$reduction has been well documented, the microbial communities associated with $\mathrm{Fe}-\mathrm{N}$ redox cycling in natural environments are not yet well under- stood. In this study, a first-generation enrichment culture of freshwater wetland sediment was subjected to a sequential shift in redox conditions [from organotrophic $\mathrm{NO}_{3}^{-}$reduction, to organotrophic $\mathrm{Fe}(\mathrm{III})$ reduction, to lithotrophic nitrate-dependent $\mathrm{Fe}$ (II) oxidation] in order to explore the coupling between microbial $\mathrm{N}$ and Fe redox cycling in sediments. Changes in microbial community structure associated with redox shifts were monitored by denaturing gradient gel electrophoresis (DGGE) analysis of polymerase chain reaction (PCR)-amplified 16S rDNA and reverse transcription polymerase chain reaction (RTPCR)-amplified 16S rRNA, and the phylogenetic association of organisms predominant in the culture was assessed through 16S rDNA clone libraries. A follow-up study evaluated the potential for $G$. metallireducens to catalyse anaerobic Fe redox cycling analogous to that observed in the enrichment culture.

\section{Results}

Most probable number (MPN) enumerations

Approximately $10^{5}$ cells (ml wet sediment) ${ }^{-1}$ of culturable (MPN assay) nitrate-dependent Fe(II)-oxidizing microorganisms were detected in Talladega Wetland surface sediment (Table 1). The abundance of culturable acetateoxidizing [nitrate- and $\mathrm{Fe}(\mathrm{III})$-reducing] microorganisms was approximately three orders of magnitude higher.

Sequential nitrate reduction, Fe(III) reduction and nitrate-dependent $\mathrm{Fe}(\mathrm{II})$ oxidation in the sediment enrichment culture

Talladega Wetland sediment served as the inoculum (1\% vol:vol) to artificial groundwater (AGW) containing $1 \mathrm{mM}$ $\mathrm{NO}_{3}^{-}, 2 \mathrm{mM}$ acetate and $50 \mathrm{mmol}^{-1}$ of synthetic high surface area goethite. Nitrate was consumed during the initial 7 days of incubation, resulting in transient accumulation of $\mathrm{NO}_{2}^{-}$and production of approximately $0.2 \mathrm{mM}$ $\mathrm{NH}_{4}^{+}$(Fig. 2A and B). The molar ratio of $\mathrm{NH}_{4}^{+}$produced to $\mathrm{NO}_{3}{ }^{-}$reduced $\left(0.280, r^{2}=0.940\right)$ was substantially lower than 1.0, which indicates that gaseous end-products such as $\mathrm{NO}, \mathrm{N}_{2} \mathrm{O}$ and/or $\mathrm{N}_{2}$ (not measured in this study) were likely produced. A decrease in $\mathrm{Fe}$ (II) $\left(0.75 \mathrm{mmol} \mathrm{I}^{-1}\right.$ of $\mathrm{Fe}$ (II) was introduced with the sediment inoculum) of approximately $0.2 \mathrm{mmol} \mathrm{I}^{-1}$ occurred during the initial $\mathrm{NO}_{3}^{-}$

Table 1. MPN enumerations of nitrate-reducing, Fe(III)-reducing and nitrate-dependent Fe(II)-oxidizing microorganisms in Talladega Wetland surface sediments.

\begin{tabular}{lll}
\hline Culture conditions & MPN (cells ml & \\
\hline Acetate $+\mathrm{NO}_{3}{ }^{-}$ & $95 \%$ confidence interval \\
Acetate $+\mathrm{Fe}(\mathrm{III})$ & $9.3 \times 10^{7}$ & $2.1 \times 10^{7}-2.7 \times 10^{8}$ \\
$\mathrm{Fe}(\mathrm{II})+\mathrm{NO}_{3}{ }^{-}$ & $2.4 \times 10^{5}$ & $2.1 \times 10^{7}-2.7 \times 10^{8}$ \\
\hline
\end{tabular}




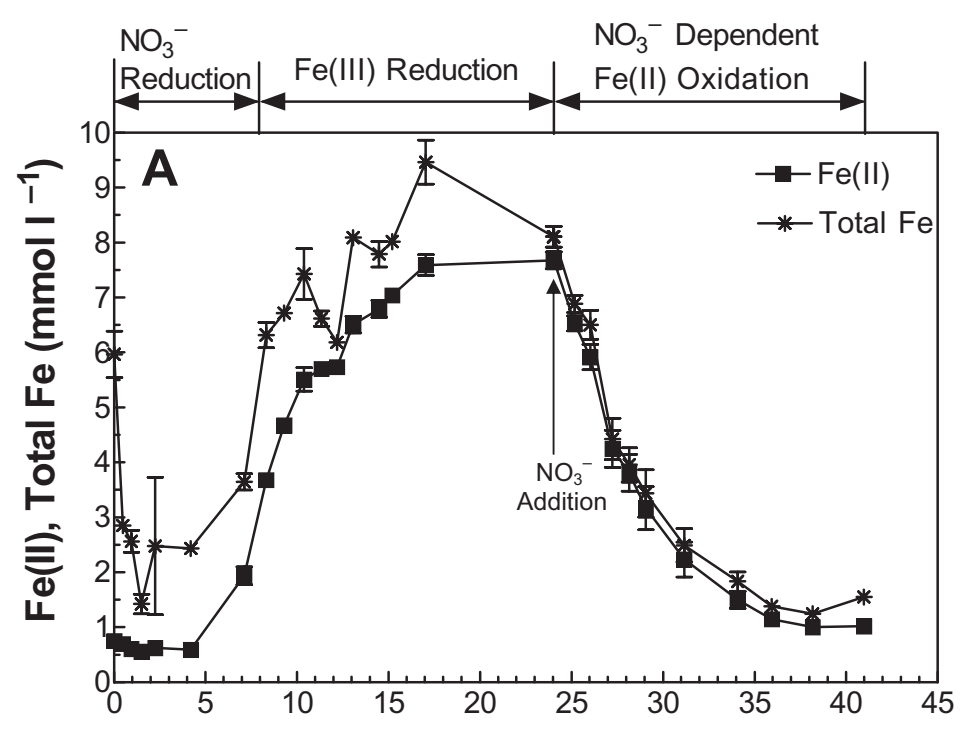

Fig. 2. Change in $0.5 \mathrm{M} \mathrm{HCl}$-extractable $\mathrm{Fe}$ (II) and total $\mathrm{Fe}(\mathrm{A})$; and $\mathrm{NO}_{3}{ }^{-}, \mathrm{NO}_{2}{ }^{-}$and $\mathrm{NH}_{4}{ }^{+}(\mathrm{B})$ over time in the wetland sediment enrichment culture. Arrow denotes $\mathrm{NO}_{3}{ }^{-}$amendment to induce nitrate-dependent $\mathrm{Fe}$ (II) oxidation. Error bars indicate standard error of triplicate cultures; bars not visible are smaller than symbol.

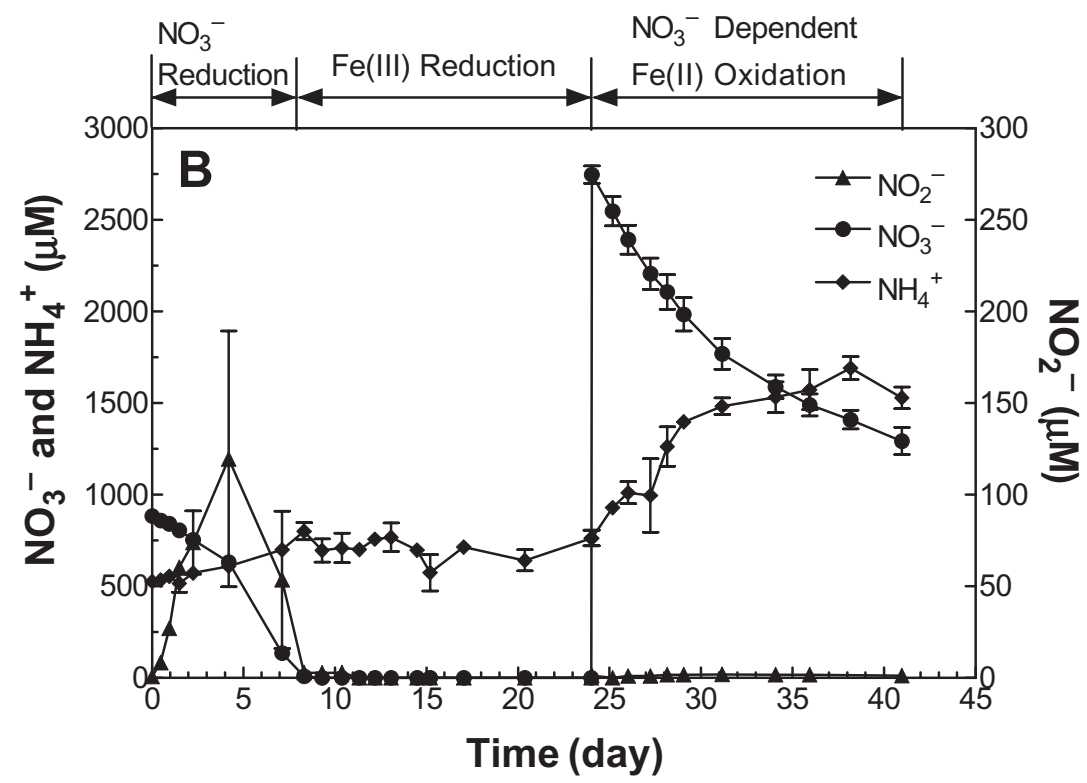

reduction phase. Because this loss of $\mathrm{Fe}(\mathrm{II})$ occurred during the period of transient $\mathrm{NO}_{2}{ }^{-}$accumulation, it is possible that abiotic $\mathrm{Fe}(\mathrm{II})$ oxidation by $\mathrm{NO}_{2}^{-}$generated during organotrophic $\mathrm{NO}_{3}^{-}$reduction was responsible for this result. However, abiotic $\mathrm{Fe}(\mathrm{II})$ oxidation by $\mathrm{NO}_{3}{ }^{-}$can be ruled out based on the results of pasteurized control cultures (see below).

$\mathrm{Fe}(\mathrm{III})$ reduction [Fe(II) accumulation] commenced once $\mathrm{NO}_{3}^{-}$decreased to below approximately $0.5 \mathrm{mM}$ (Fig. 2A and B) and continued until acetate was depleted (data not shown), yielding $7.6 \mathrm{mmol}^{-1}$ of $0.5 \mathrm{M} \mathrm{HCl}-$ extractable $\mathrm{Fe}(\mathrm{II})$ [equivalent to approximately $15 \%$ of the initial $\mathrm{Fe}(\mathrm{III})$ content of the slurry]. Approximately $35 \%$ of the $\mathrm{HCl}$-extractable $\mathrm{Fe}(\mathrm{II})$ was present as dissolved $\mathrm{Fe}(\mathrm{II})$ at the end of the $\mathrm{Fe}(\mathrm{III})$ reduction phase. Reduction of the synthetic goethite resulted in an obvious colour change in the mineral from gold-yellow to dark greenish-brown. Mixed $\mathrm{Fe}(\mathrm{II})-\mathrm{Fe}(\mathrm{III})$ phases such as magnetite and/or green rust were not detected by X-ray diffraction (XRD) (Fig. 3A). However, comparison of a low-temperature (77K) Mössbauer spectra for the reduced goethite with that from a sample of microbially reduced (Shewanella putrefaciens in AQDS and $\mathrm{HCO}_{3}{ }^{-}$containing medium) natural goethite (Kukkadapu et al., 2001) indicated the presence of trace amounts of $\mathrm{Fe}(\mathrm{II})$ associated with green rust (Fig. 3B). The formation of only minor amounts of distinct $\mathrm{Fe}(\mathrm{II})$-bearing mineral phases is consistent with other recent studies of the end-products of natural and synthetic goethite reduction by dissimilatory $\mathrm{Fe}(\mathrm{III})$-reducing bacteria (Kukkadapu et al., 2001; Zachara et al., 2001). The vast majority of solidassociated $\mathrm{Fe}(\mathrm{II})$ was presumably sorbed and/or 

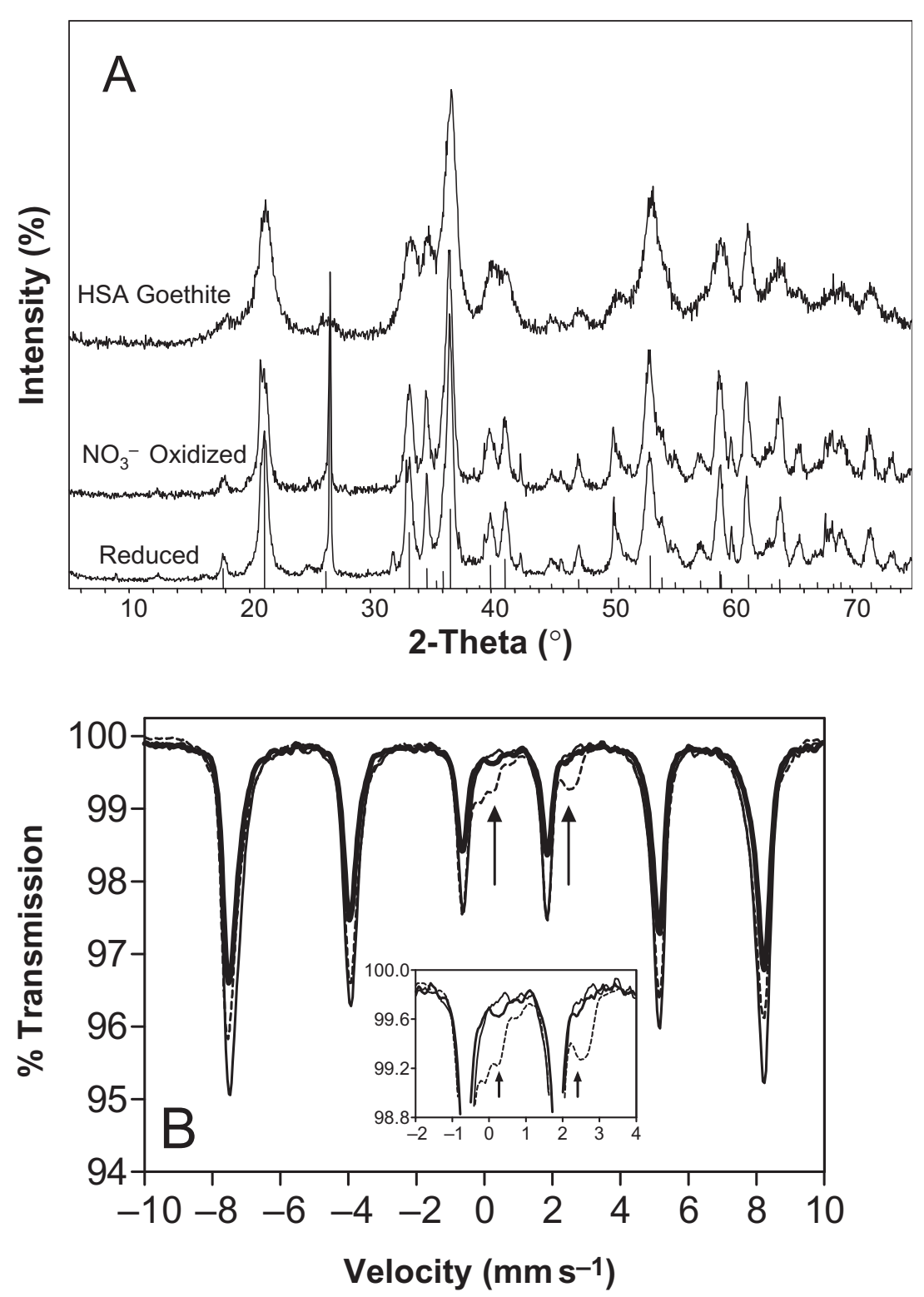

Fig. 3. X-ray diffraction (A) and 77K Mössbauer (B) spectra of microbially reduced and nitrate-dependent oxidized HSA goethite from the sediment enrichment culture. The 'HSA goethite' spectrum in panel $A$ is from a mineral preparation similar (but not identical) to the material used in the enrichment culture experiment; major peak lines for a reference goethite phase are shown at bottom. Thick and thin solid lines in panel B correspond to microbially reduced and nitrate-dependent oxidized HSA goethite, respectively, from the sediment enrichment culture. The dashed line shows results for microbially reduced natural goethite from Kukkadapu and colleagues (2001). Arrows in panel $\mathrm{B}$ point to an $\mathrm{Fe}(\mathrm{II})$ doublet (superimposed on the goethite sextet) that can be attributed to green rust (Kukkadapu et al., 2001). surface-precipitated on residual Fe(III) oxide surfaces (Zachara et al., 2001; Roden and Urrutia, 2002).

Addition of $\mathrm{NO}_{3}^{-}$following cessation of $\mathrm{Fe}(\mathrm{III})$ reduction resulted in immediate oxidation of $\mathrm{Fe}(\mathrm{II})$ and consumption of $\mathrm{NO}_{3}{ }^{-}$(Fig. 2A). Subcultures removed from the primary enrichment cultures and pasteurized prior to $\mathrm{NO}_{3}{ }^{-}$readdition showed no $\mathrm{Fe}(\mathrm{II})$ oxidation or $\mathrm{NO}_{3}{ }^{-}$consumption (Fig.4). Biological oxidation caused the microbially reduced goethite to change from greenish-brown back to its original goldish-yellow colour. Approximately $85 \%$ of $0.5 \mathrm{M} \mathrm{HCl}$-extractable $\mathrm{Fe}(\mathrm{II})$ was oxidized within 15 days in live cultures. Total $0.5 \mathrm{M} \mathrm{HCl}$-extractable $\mathrm{Fe}$ $[\mathrm{Fe}(\mathrm{II})+\mathrm{Fe}(\mathrm{III})]$ decreased in parallel with $\mathrm{HCl}$-extractable $\mathrm{Fe}$ (II) during nitrate-dependent Fe(II) oxidation (Fig. 2A), which suggests the production of crystalline $\mathrm{Fe}(\mathrm{III})$ oxide phases not soluble in $0.5 \mathrm{M} \mathrm{HCl}$. X-ray diffraction and Mössbauer spectra of the nitrate-oxidized material were virtually identical to those of the reduced mineral (Fig. 3), suggesting that goethite was likely reformed.

In contrast to the initial organotrophic $\mathrm{NO}_{3}{ }^{-}$reduction phase of the experiment, nitrate-dependent $\mathrm{Fe}(\mathrm{II})$ oxidation did not result in the transient accumulation of $\mathrm{NO}_{2}^{-}$ $(<2 \mu \mathrm{M})$. Significant accumulation of $\mathrm{NH}_{4}^{+}$(approximately $0.9 \mathrm{mM}$ ) took place during nitrate-dependent Fe(II) oxidation (Fig. 2B). The molar ratio of $\mathrm{NO}_{3}{ }^{-}$reduced to $\mathrm{Fe}(\mathrm{II})$ oxidized $\left(0.191, r^{2}=0.983\right)$ was higher than the theoretical ratio for $\mathrm{Fe}(\mathrm{II})$ oxidation coupled to $\mathrm{NO}_{3}{ }^{-}$reduction to $\mathrm{NH}_{4}{ }^{+}(0.125)$, which indicates that small quantities of endproducts other than $\mathrm{NH}_{4}^{+}$(e.g. $\mathrm{N}_{2}, \mathrm{NO}$, and/or $\mathrm{N}_{2} \mathrm{O}$ ) were likely produced. 


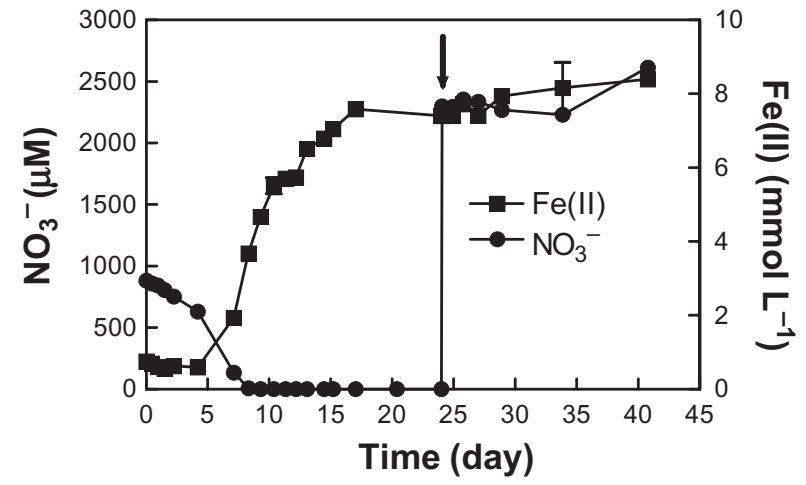

Fig. 4. Change in $\mathrm{NO}_{3}{ }^{-}$and $0.5 \mathrm{M} \mathrm{HCl}$-extractable $\mathrm{Fe}(\mathrm{II})$ over time in pasteurized subsamples of the wetland sediment enrichment culture amended with approximately $2.5 \mathrm{mM} \mathrm{NO}_{3}{ }^{-}$. The arrow indicates time at which the enrichment culture was pasteurized and amended with $\mathrm{NO}_{3}{ }^{-}$. Error bars indicate standard error of triplicate cultures; bars not visible are smaller than symbol.

\section{Changes in microbial community structure during $\mathrm{Fe}-\mathrm{N}$ redox metabolism}

Denaturing gradient gel electrophoresis analysis of PCRamplified 16S rDNA and 16S rRNA RT-PCR products revealed a change in microbial community structure as redox conditions shifted from $\mathrm{NO}_{3}^{-}$reduction to $\mathrm{Fe}(\mathrm{III})$ reduction (Fig. 5). The DGGE results must be interpreted as a preliminary fingerprint of microbial community structure, as repeated attempts to amplify bands excised from the denaturing gradient gel failed. Phylogenetic association of dominant members of the microbial community from each phase of the experiment was achieved via construction and sequencing of 165 rDNA clone libraries.

The clone libraries verified that a substantial change in community structure took place upon the shift from nitratereducing to $\mathrm{Fe}(\mathrm{III})$-reducing conditions (Fig. 6A). One of the most significant changes was an increase in the number of clones associated with the beta subclass of the Proteobacteria (Betaproteobacteria), from approximately $3 \%$ under nitrate-reducing conditions to approximately $60 \%$ under Fe(III)-reducing conditions (Fig. 6A). Dechloromonas $\mathrm{sp}$. was the most frequently identified (75\%, Fig. 6C) phylogenetic group among the Betaproteobacteria clones. A significant fraction (25\%) of clones from the $\mathrm{Fe}$ (III)-reducing phase were associated with the delta subclass of the Proteobacteria (Deltaproteobacteria) (Fig. 6A). Most of these Deltaproteobacteria clones (66\%, Fig. $6 \mathrm{~B}$ ) were $\geq 95 \%$ similar to organisms from the genus Geobacter, a well-recognized group of dissimilatory $\mathrm{Fe}(\mathrm{III})$-reducing bacteria (Lovley, 2002). This observation is consistent with the previous documentation of significant (approximately $10^{6} \mathrm{ml}^{-1}$ ) numbers of culturable acetate-oxidizing, Fe(III)-reducing Geobacter sp. in Talladega Wetland surface sediments (Coates et al., 1996).

The 16S rDNA/rRNA fingerprints from the nitrate- dependent $\mathrm{Fe}(\mathrm{II})$ oxidation phase were similar to those from the $\mathrm{Fe}(\mathrm{III})$ reduction phase (Fig. 5), which suggests that the microbial community active during $\mathrm{Fe}(\mathrm{III})$ reduction was also responsible for nitrate-dependent Fe(II) oxidation. The corresponding clone libraries revealed only a small shift in community structure. The frequency of Betaproteobacteria clones increased slightly from $60 \%$ to $65 \%$, and the frequency of Deltaproteobacteria clones decreased slightly from $25 \%$ to $22 \%$ (Fig. 6A). Within the Betaproteobacteria, the frequency of clones identified as Dechloromonas sp. decreased (to 40\%) and clones identified as Azospira sp. (11\%), Aquaspirillium sp. (11\%), Aquabacterium sp. (4\%) appeared along with several clones $(33 \%)$ that were not classified within the Betaproteobacteria (Fig. 6C).

Sequential $\mathrm{NO}_{3}^{-}$Reduction, $\mathrm{Fe}(\mathrm{III})$ Reduction and nitratedependent $\mathrm{Fe}(\mathrm{II})$ oxidation by $\mathrm{G}$. metallireducens

The potential for G. metallireducens to carry-out anaerobic Fe redox cycling was examined in an experiment analogous to the wetland sediment enrichment culture study. $\mathrm{NO}_{3}{ }^{-}$was reduced within the first few days of incubation, resulting in a transient accumulation of $\mathrm{NO}_{2}^{-}(61 \mu \mathrm{M})$ and stoichiometric production of $\mathrm{NH}_{4}{ }^{+}\left(97 \%\right.$ of added $\mathrm{NO}_{3}{ }^{-}$, Fig. 7). The presence of $\mathrm{NO}_{3}^{-}$did not inhibit $\mathrm{Fe}(\mathrm{III})$ reduction, as evidenced by accumulation of $\mathrm{Fe}(\mathrm{II})$ concurrent with $\mathrm{NO}_{3}{ }^{-}$reduction. When $\mathrm{NO}_{3}{ }^{-}$was added upon cessa-

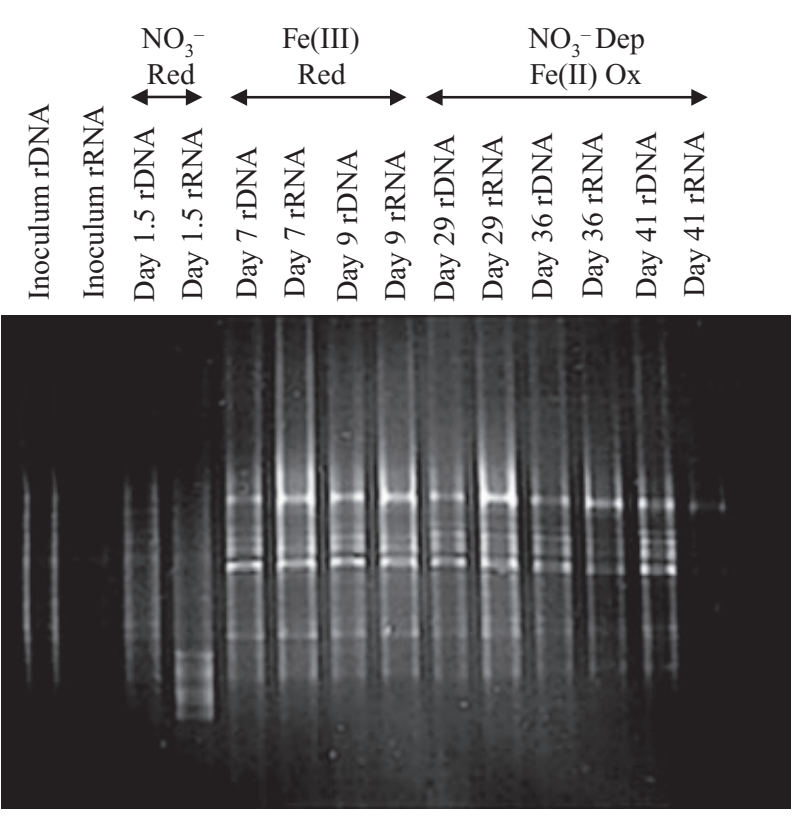

Fig. 5. DGGE analysis of PCR-amplified $16 \mathrm{~S}$ rDNA and RT-PCRamplified 16S rRNA from the enrichment culture. Time (day) corresponds to the $x$-axis in Fig. 2. 'Inoculum' refers to $16 \mathrm{~S}$ rDNA and $16 \mathrm{~S}$ rRNA extracted from the sediment used to inoculate the enrichment cultures. 


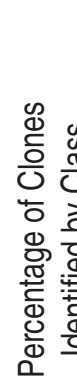

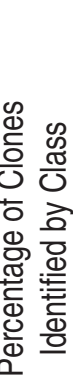
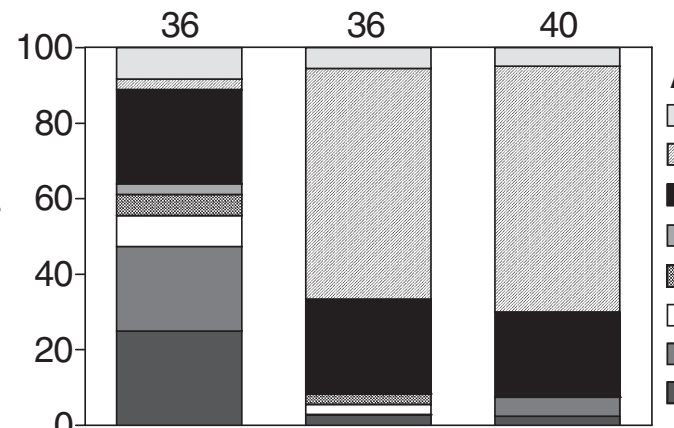

A

Alphaproteobac

Betaproteobac

Deltaproteobac

Gammaproteobac

Actinobacteria

Bacteroidetes

Other

Unclassified

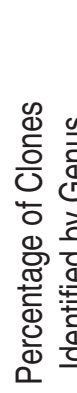

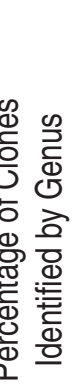

9

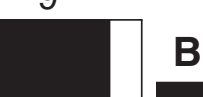

B 9 9

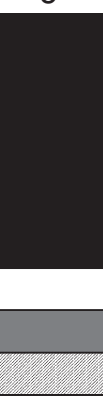

22
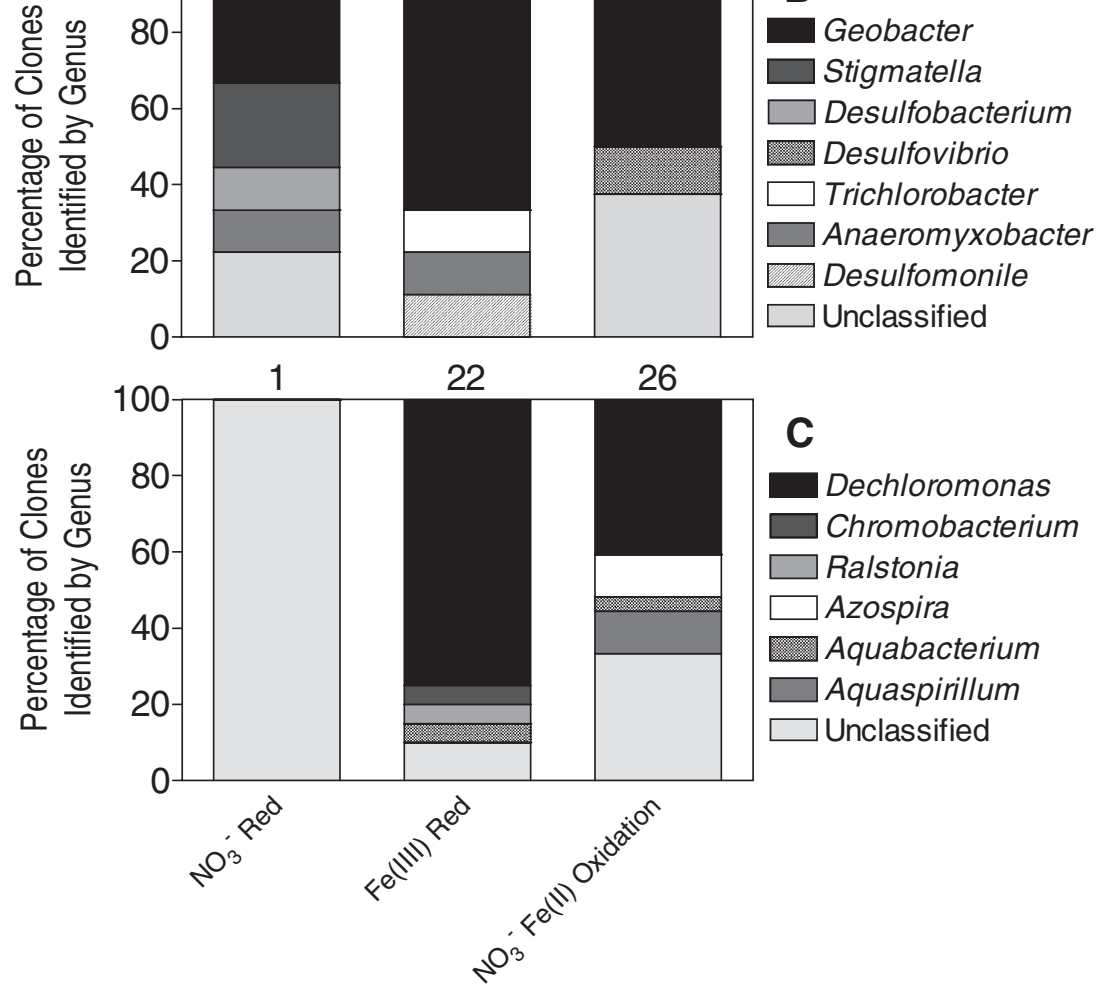

Fig. 6. Relative proportions of 16S rRNA gene sequences in clone libraries from the enrichment culture.

A. Sequences within the domain Bacteria. 'Other' represents Verrucomicrobiae, Deferribacterales, Cytophaga, Planctomycetacia, Fusobacteria and Acidobacteria combined. B. Sequences with $\geq 95 \%$ sequence similarity to known genera within the

Deltaproteobacteria.

C. Sequences with $\geq 95 \%$ sequence similarity to known genera within the Betaproteobacteria. 'Unclassified' represents sequences with $<95 \%$ sequence similarity to known genera. Numbers above the bars indicate the total number of clones within a given group. tion of $\mathrm{Fe}(\mathrm{III})$ reduction, $86 \%$ of $0.5 \mathrm{M} \mathrm{HCl}$-extractable $\mathrm{Fe}(\mathrm{II})$ was oxidized within 4 days coupled to consumption of $\mathrm{NO}_{3}{ }^{-}$and accumulation of $\mathrm{NH}_{4}^{+}$(Fig. 7). Fe(II) oxidation then continued at a slower rate, resulting in the consumption of virtually all (93\%) of the $0.5 \mathrm{M} \mathrm{HCl}$-extractable $\mathrm{Fe}(\mathrm{II})$. The molar ratios of $\mathrm{NO}_{3}{ }^{-}$reduced to $\mathrm{Fe}(\mathrm{II})$ oxidized and $\mathrm{NH}_{4}{ }^{+}$produced to $\mathrm{Fe}(\mathrm{II})$ consumed $\left(0.175, r^{2}=0.989\right.$ and $0.189, r^{2}=0.897$, respectively) were slightly higher than the theoretical ratio for $\mathrm{NO}_{3}{ }^{-}$reduction to $\mathrm{NH}_{4}{ }^{+}$coupled to $\mathrm{Fe}(\mathrm{II})$ oxidation (0.125).

\section{Discussion}

\section{Nitrate inhibition of $\mathrm{Fe}(\mathrm{III})$ reduction}

Nitrate inhibited $\mathrm{Fe}(\mathrm{III})$ reduction in the sediment enrich- ment culture (Fig. 2A), a result consistent with previous studies of the influence of $\mathrm{NO}_{3}{ }^{-}$on $\mathrm{Fe}(\mathrm{III})$ reduction in pure and mixed cultures of $\mathrm{Fe}$ (III)-reducing bacteria (Obuekwe et al., 1981; Sorensen, 1982; Jones et al., 1983; DiChristina, 1992; Achtnich et al., 1995; Finneran et al., 2002; Cooper et al., 2003). In contrast, $\mathrm{Fe}(\mathrm{III})$ was reduced simultaneously with $\mathrm{NO}_{3}{ }^{-}$in the $\mathrm{G}$. metallireducens cell suspension. The latter result may be attributed to the presence of a relatively high initial cell density (approximately $10^{8}$ cells $\mathrm{ml}^{-1}$ ) and an excess of electron donor, which allowed both processes to occur together. Similar experiments using a 10-fold lower initial G. metallireducens cell density showed inhibition of $\mathrm{Fe}$ (III) reduction by $\mathrm{NO}_{3}{ }^{-}$comparable to that observed in the wetland sediment enrichment culture. 


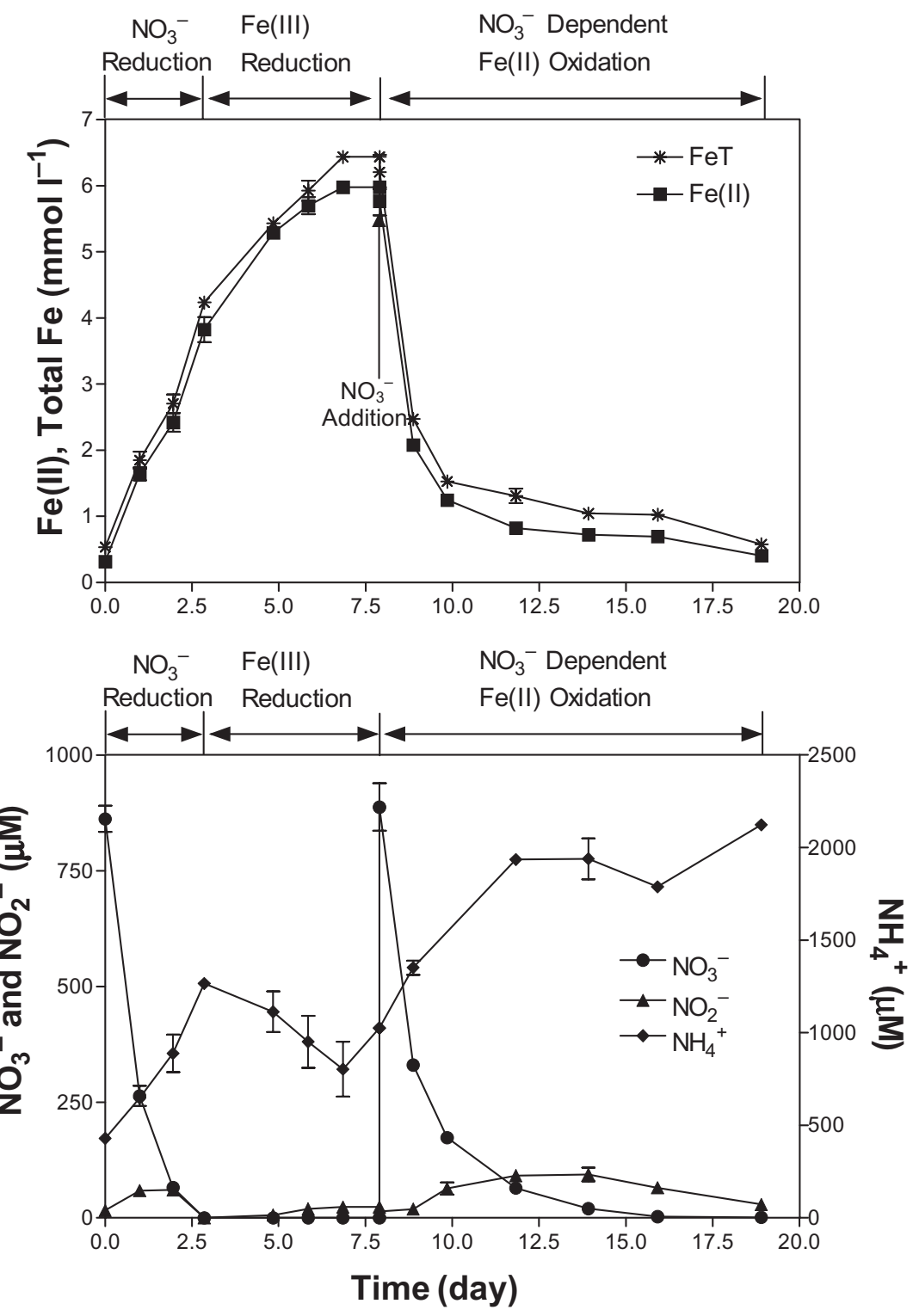

Fig. 7. Change in $0.5 \mathrm{M} \mathrm{HCl}$-extractable $\mathrm{Fe}(\mathrm{II})$, and total $\mathrm{Fe}(\mathrm{A})$ and $\mathrm{NO}_{3}{ }^{-}, \mathrm{NO}_{2}{ }^{-}, \mathrm{NH}_{4}{ }^{+}(\mathrm{B})$ over time in growth medium inoculated with nitrategrown G. metallireducens cells. Arrow denotes the $\mathrm{NO}_{3}{ }^{-}$to induce nitrate-dependent $\mathrm{Fe}(\mathrm{II})$ oxidation. Error bars indicate standard error of triplicate cultures; bars not visible are smaller than symbol.

\section{Mechanism and end-products of nitrate-dependent Fe(II) oxidation}

The addition of $\mathrm{NO}_{3}^{-}$following the cessation of $\mathrm{Fe}(\mathrm{III})$ reduction resulted in immediate and rapid oxidation of both aqueous and solid-phase $\mathrm{Fe}$ (II) and production of substantial quantities of $\mathrm{NH}_{4}^{+}$(Fig. 2). Abiotic oxidation of $\mathrm{Fe}(\mathrm{II})$ by gaseous end-products such as $\mathrm{NO}$ and $\mathrm{N}_{2} \mathrm{O}$ can be ruled out based on previous studies in which $\mathrm{NO}$ and $\mathrm{N}_{2} \mathrm{O}$ additions to soil slurries containing $\mathrm{Fe}(\mathrm{II})$ did not result in an increase in $\mathrm{Fe}(\mathrm{III})$ concentrations (Kluber and Conrad, 1998). Moreover, lack of significant Fe(II) oxidation in pasteurized cultures (Fig. 4) indicated that $\mathrm{NO}_{3}{ }^{-}$did not abiotically oxidize the microbially reduced goethite. This result is consistent with previously reported results in which abiotic oxidation of $\mathrm{Fe}(\mathrm{II})$ by $\mathrm{NO}_{3}^{-}$was not observed in suspensions of microbially reduced goethite or other Fe(III) oxide-bearing solids (Weber et al., 2001).

Production of $\mathrm{NH}_{4}^{+}$as an end-product of biological nitrate-dependent $\mathrm{Fe}$ (II) oxidation has not been previously reported. To date, only studies of abiotic $\mathrm{NO}_{3}{ }^{-}$reduction coupled to oxidation of green rust compounds have demonstrated $\mathrm{NH}_{4}^{+}$as a predominant end-product of nitratedependent Fe(II) oxidation (Hansen et al., 1996; Hansen et al., 2001). Green rust was not identified as a major product of microbial goethite reduction generated in this study nor in previous studies using similar culture conditions (Cooper et al., 2000; Kukkadapu et al., 2001; Zachara et al., 2001). This result, together with the lack of $\mathrm{Fe}(\mathrm{II})$ oxidation in pasteurized controls, argues against 
abiotic reaction of $\mathrm{NO}_{3}{ }^{-}$with green rust as a mechanism for $\mathrm{NH}_{4}^{+}$production in the enrichment culture. A recent report documented green rust as a minor end-product of soluble $\mathrm{Fe}(\mathrm{II})\left(\mathrm{FeCl}_{2}\right)$ oxidation coupled to $\mathrm{NO}_{3}{ }^{-}$reduction by Azospira suillum (Chaudhuri et al., 2001). These findings suggest the possibility that green rust compounds, generated during the initial stages of nitrate-dependent $\mathrm{Fe}$ (II) oxidation, served as a reductant for further (i.e. autocatalytic) abiotic reduction of $\mathrm{NO}_{3}{ }^{-}$to $\mathrm{NH}_{4}{ }^{+}$in our experiments. However, Chaudhuri and colleagues (2001) reported that $\mathrm{NO}_{3}{ }^{-}$was stoichiometrically reduced to $\mathrm{N}_{2}$ under biological $\mathrm{Fe}$ (II)-oxidizing conditions, whereas stoichiometric reduction of $\mathrm{NO}_{3}^{-}$to $\mathrm{NH}_{4}^{+}$is observed during abiotic oxidation of synthetic chloride green rust [Fe(II) $)_{\mathrm{GR}}$ cl] (Hansen et al., 2001). These results argue against a green rust-mediated autocatalytic mechanism for abiotic $\mathrm{Fe}(\mathrm{II})$ oxidation in the experiments of Chaudhuri and colleagues (2001), further supporting an enzymatic Fe(II) oxidation mechanism. Together these previous observations reinforce the argument that the $\mathrm{NH}_{4}^{+}$produced during nitrate-dependent $\mathrm{Fe}(\mathrm{II})$ oxidation in this study was the result of microbial (enzymatic) catalysis rather than abiotic reaction(s) with a green rust intermediate.

Oxidation of $\mathrm{Fe}$ (II) (soluble and solid-phase) coupled to $\mathrm{NO}_{3}{ }^{-}$reduction during the final phase of the sediment enrichment, as well as the pure culture study with $G$. metallireducens (Fig.7), resulted in a decline in total $0.5 \mathrm{M} \mathrm{HCl}$-extractable $\mathrm{Fe}$ in parallel with the decrease in $\mathrm{Fe}$ (II) (Fig. 2A). These results suggest that crystalline $\mathrm{Fe}$ (III) oxide phases were formed, in contrast to previous studies which indicated that nitrate-dependent $\mathrm{Fe}(\mathrm{II})$ oxidation resulted in the formation of poorly crystalline $\mathrm{Fe}$ (III) oxide (Straub et al., 1996; 1998). These contrasting results may be attributed to the relatively low concentration of phosphate in the culture medium used in our experiments $(0.05 \mathrm{mM}$, compared with $1.5 \mathrm{mM}$ in the culture medium employed by Straub et al., 1996, 1998): other studies with the Straub and colleagues (1996) enrichment culture (Weber, 2002) have shown that a decrease in phosphate from approximately $1.5-0.05 \mathrm{mM}$ resulted in a progressive increase in the formation of crystalline (goethite, lepidocrocite) versus amorphous phases. These data suggest that in the absence of high concentrations of inhibitors of $\mathrm{Fe}$ (III) oxide crystallization such as phosphate (Cornell and Schwertmann, 1996), nitrate-dependent $\mathrm{Fe}$ (II) oxidation is likely to result in the production of predominantly crystalline $\mathrm{Fe}(\mathrm{III})$ oxide phases which are insoluble in dilute $(0.5 \mathrm{M}) \mathrm{HCl}$. Given that solid-associated $\mathrm{Fe}$ (II) was the dominant form of $\mathrm{Fe}$ (II) available for nitratedependent oxidation in the enrichment culture experiment, and that virtually all of the $\mathrm{Fe}(\mathrm{II})$ oxidized in this experiment was lost from the $0.5 \mathrm{M} \mathrm{HCl}$-extractable pool, our results indicate that both aqueous and solid-phase $\mathrm{Fe}(\mathrm{II})$ are subject to conversion to crystalline Fe(III) oxides dur- ing nitrate-dependent $\mathrm{Fe}(\mathrm{II})$ oxidation. The similarity of XRD and Mössbauer spectra for the reduced and nitratedependent oxidized goethite (Fig. 3) indicate that goethite phases with particle size and crystallinity nearly identical to that of the starting material were regenerated during nitrate-dependent oxidation.

\section{Microbial communities associated with $\mathrm{Fe}-\mathrm{N}$ redox cycling}

Although previous studies have demonstrated that pure cultures of organotrophic denitrifying bacteria are capable of nitrate-dependent Fe(II) oxidation (Straub et al., 1996; Benz et al., 1998; Chaudhuri et al., 2001), the majority of the organisms detected during nitrate-dependent Fe(II) oxidation in this study were more similar to those present during the $\mathrm{Fe}(\mathrm{III})$ reduction phase than in the organotrophic $\mathrm{NO}_{3}^{-}$reduction phase (Figs 5 and 6). These results indicate that microorganisms capable of both $\mathrm{Fe}$ (III) reduction and nitrate-dependent $\mathrm{Fe}$ (II) oxidation were responsible for the $\mathrm{Fe}$ (II) oxidation activity observed in the latter stages of the experiment. The rapid onset of nitrate-dependent Fe(II) oxidation following Fe(III) reduction supports the idea that $\mathrm{Fe}(\mathrm{III})$-reducing microorganisms which proliferated during the $\mathrm{Fe}(\mathrm{III})$ reduction phase of the experiment were responsible for subsequent nitratedependent $\mathrm{Fe}(\mathrm{II})$ oxidation. Organisms such as G. metallireducens (Lovley and Phillips, 1988) and other members of Geobacteraceae (Lovley, 2002), which are capable of organotrophic growth with either $\mathrm{NO}_{3}^{-}$or $\mathrm{Fe}(\mathrm{III})$ as an electron acceptor, are logical candidates for such organisms.

In light of the recent observation by Finneran and colleagues (2002) that G. metallireducens can couple oxidation of soluble $\mathrm{Fe}(\mathrm{II})$ to reduction of $\mathrm{NO}_{3}{ }^{-}$, we examined whether $G$. metallireducens could catalyse nitratedependent oxidation of microbially reduced goethite under conditions analogous to the wetland sediment enrichment culture. The results provided clear evidence of such activity (compare Figs 2 and 7). The large proportion of Geobacter sp. 16S rDNA sequences in clone libraries from the nitrate-dependent $\mathrm{Fe}(\mathrm{II})$ oxidation phase of the experiment (Fig. 6B), the persistence (suggested by DGGE analysis; see Fig. 5) of a few key genotypes throughout the Fe(III) reduction and nitrate-dependent $\mathrm{Fe}$ (II) oxidation phases, and the production of $\mathrm{NH}_{4}^{+}$as an end-product of nitratedependent $\mathrm{Fe}(\mathrm{II})$ oxidation sp., provides convincing evidence for the role of Geobacter in nitrate-dependent Fe(II) oxidation in the wetland sediment. It is thus far unknown whether G. metallireducens and other nitrate-reducing members of Geobacteraceae are able to conserve energy for growth/maintenance from nitrate-dependent $\mathrm{Fe}(\mathrm{II})$ oxidation.

The detection of significant numbers of $16 \mathrm{~S}$ rDNA 
clones associated with Dechloromonas sp. and other organisms from the Betaproteobacteria in libraries from the $\mathrm{Fe}(\mathrm{III})$-reducing and nitrate-dependent $\mathrm{Fe}$ (II) oxidation phases in the enrichment culture (Fig. 6A and C) suggests the possibility that such organisms may have also been involved in anaerobic Fe-N redox cycling. This idea is supported by the fact that nitrate-dependent Fe(II) oxidation has been described within the Betaproteobacteria, specifically in Dechloromonas sp. and Azospira sp. (Bruce et al., 1999; Chaudhuri et al., 2001), as well as in the nitrate-dependent $\mathrm{Fe}(\mathrm{II})$-oxidizing bacterium $\mathrm{BrG} 2$, which has $98 \%$ sequence identity with Aquabacterium commune (Buchholz-Cleven et al., 1997). Dechloromonas sp., Azospira sp. and Aquaspirillum sp. have been described as denitrifiers which produce $\mathrm{N}_{2}$ as the reduced $\mathrm{N}$ product (Mahne and Tiedje, 1995; Chaudhuri et al., 2001; Coates et al., 2001). Given that chemical analysis of the wetland sediment enrichment identified $\mathrm{NH}_{4}{ }^{+}$as a primary product of nitrate-dependent $\mathrm{Fe}(\mathrm{II})$ oxidation, these bacteria were obviously not the only active members of the nitratedependent Fe(II)-oxidizing microbial community. The combined results of the DGGE and 16S rDNA clone library analyses suggest (but do not prove) that organisms related to Dechloromonas sp. were abundant during $\mathrm{Fe}$ (III) reduction as well as nitrate-dependent Fe(II) oxidation. Although dissimilatory Fe(III) reduction by Dechloromonas $\mathrm{sp}$. has not been observed in pure culture, $\mathrm{Fe}(\mathrm{III})$ reduction by Betaproteobacteria has been identified in Ferribacterium limneticum (Cummings et al., 1999), whose $16 \mathrm{~S}$ rRNA gene sequence is $99 \%$ similar to that of Dechloromonas aromatica strain RCB (Coates et al., 2001).

\section{Biogeochemical significance}

Oxidation of soluble and solid-phase $\mathrm{Fe}$ (II) coupled to $\mathrm{NO}_{3}{ }^{-}$reduction provides the potential for a tight coupling between $\mathrm{N}$ and Fe redox cycles in sedimentary environments (Straub et al., 2001; 2004). Such coupling is likely to be particularly significant at the interface between $\mathrm{NO}_{3}^{-}$ and $\mathrm{Fe}$ (III) reduction zones in sediments influenced by periodic fluctuations in the inputs of organic carbon and oxidants (see Fig. 1). These fluctuations are common in shallow subsurface environments, which are typically very active hydrologically and support a rich and diverse microflora (Chapelle, 2001). When inputs of organic carbon are relatively high compared with $\mathrm{NO}_{3}{ }^{-}$, organotrophic $\mathrm{NO}_{3}{ }^{-}$ reduction may exhaust available $\mathrm{NO}_{3}^{-}$, thus allowing microbial $\mathrm{Fe}(\mathrm{III})$ reduction and associated production of aqueous $\mathrm{Fe}(\mathrm{II})$ and/or $\mathrm{Fe}(\mathrm{II})$-bearing solid-phases to occur. During subsequent periods of reduced organic carbon loading, rates of $\mathrm{NO}_{3}{ }^{-}$re-supply may exceed rates of organotrophic $\mathrm{NO}_{3}^{-}$reduction, resulting in the availability of nitrate for lithotrophic, nitrate-dependent Fe(II) oxida- tion. In this way, reducing equivalents stored in the form of aqueous and/or Fe(II)-bearing solid-phases may serve as an significant source of energy for microbial metabolism during periods of reduced organic carbon input. Organisms such as $G$. metallireducens which are capable of switching between organotrophic nitrate and/or Fe(III) reduction and nitrate-dependent $\mathrm{Fe}$ (II) oxidation are likely to have a competitive advantage in such environments. Detailed studies of the response of sediment microbial communities to repeated fluctuations in organic carbon and $\mathrm{NO}_{3}^{-}$loading are required to verify this hypothesis.

Nitrate-dependent $\mathrm{Fe}$ (II) oxidation has the potential to significantly influence patterns of organic and inorganic contaminant transformations in anaerobic soils and sediments through local consumption of $\mathrm{NO}_{3}{ }^{-}$and regeneration of $\mathrm{Fe}$ (III) oxides. Straub and colleagues (2004) recently described an example of the potential impact of $\mathrm{Fe}-\mathrm{N}$ redox cycling on benzoate oxidation in anaerobic sediments. A co-culture consisting of $\mathrm{Fe}$ (III)-reducing (Geobacter bremensis) and a consortia of nitratedependent $\mathrm{Fe}(\mathrm{II})$-oxidizing organisms (the stable enrichment culture described in Straub et al., 1996) was able to oxidize benzoate coupled to $\mathrm{Fe}(\mathrm{III})$ oxide reduction through a process in which a relatively small amount of amorphous $\mathrm{Fe}$ (III) oxide was continuously recycled via nitrate-dependent $\mathrm{Fe}(\mathrm{II})$ oxidation. Such interactions expand the range of potential mechanisms by which natural and contaminant organic compounds may be oxidized in anaerobic soils and sediments. Recent examples of the influence of anaerobic $\mathrm{Fe}-\mathrm{N}$ redox cycling on inorganic biogeochemical processes include the oxidation and coprecipitation of $\mathrm{Fe}(\mathrm{III})$ and $\mathrm{As}(\mathrm{V})$ in stratified lake waters (Senn and Hemond, 2002), and the oxidation of U(IV) by $\mathrm{Fe}$ (III) generated during nitrate-dependent Fe(II) oxidation in uranium-contaminated subsurface sediments (Finneran et al., 2002). In addition, formation of relatively crystalline $\mathrm{Fe}$ (III) oxides during biological oxidation of aqueous and solid-phase $\mathrm{Fe}(\mathrm{II})$, as observed in this study, could contribute to the sequestration of metal-radionuclide contaminants by incorporation of the metal or radionuclide into the oxide lattice and/or physical envelopment of the contaminant(s). Lack and colleagues (2002) demonstrated the potential for immobilization of $\mathrm{Co}(\mathrm{II})$ and $\mathrm{U}(\mathrm{VI})$ in crystalline $\mathrm{Fe}$ (III) oxides formed during nitrate-dependent $\mathrm{Fe}$ (II) oxidation. Because crystalline Fe(III) oxides are not as available to microbial $\mathrm{Fe}(\mathrm{III})$ reduction as amorphous $\mathrm{Fe}$ (III) oxides, metal-radionuclide contaminants immobilized in crystalline biogenic $\mathrm{Fe}$ (III) oxides may be resistant to remobilization with the onset of $\mathrm{Fe}$ (III)-reducing conditions. Further studies of the influence of solid-phase $\mathrm{Fe}(\mathrm{II})-\mathrm{Fe}(\mathrm{III})$ conversions on metal-radionuclide speciation are needed to determine the long-term effects of $\mathrm{Fe}-$ $\mathrm{N}$ redox cycling on the mobility of such contaminants in sediments. 


\section{Experimental procedures}

\section{Most probable number enumerations}

The abundance of culturable acetate-oxidizing nitrate-reducing bacteria, acetate-oxidizing Fe(III)-reducing bacteria, and $\mathrm{Fe}(\mathrm{II})$-oxidizing nitrate-reducing bacteria in freshwater wetland surface sediments were estimated using a three-tub MPN technique (Woomer, 1994). A freshwater wetland sediment core was collected from a small (15 ha) wetland located in the Talladega National Forest, Hale County, Alabama. Previous studies have documented the quantitative significance of microbial $\mathrm{Fe}(\mathrm{III})$ reduction and $\mathrm{Fe}$ redox cycling on sediment carbon metabolism and energy flow in this environment (Roden and Wetzel, 1996). Upon return to the laboratory, sediment from the upper $5 \mathrm{~cm}$ of the core was homogenized, sieved $(1 \mathrm{~mm})$, and placed under $\mathrm{N}_{2}$ at room temperature. Triplicate pressure tubes containing sterile, anaerobic $\left(\mathrm{N}_{2}: \mathrm{CO}_{2} ; 90: 10\right)$ AGW medium (10 mM PIPES, $2 \mathrm{mM} \mathrm{NaHCO}_{3}, 5 \mathrm{mM} \mathrm{NH}_{4} \mathrm{Cl}, 0.5 \mathrm{mM} \mathrm{KH}_{2} \mathrm{PO}_{4}, \mathrm{pH}$ 6.8) were inoculated with serially diluted anaerobic, homogenized sediment. For enumeration of acetate-oxidizing, $\mathrm{NO}_{3}{ }^{-}$-reducing bacteria, tubes were amended with $5 \mathrm{mM} \mathrm{NaNO}_{3}$ and $10 \mathrm{mM}$ $\mathrm{Na}$-acetate from sterile, anaerobic stock solutions. Acetateoxidizing, $\mathrm{Fe}(\mathrm{III})$-reducing bacteria were enumerated in medium amended with $10 \mathrm{mmol} \mathrm{I}^{-1}$ of synthetic hydrous ferric oxide prior to autoclaving. The culture tubes were then amended with $10 \mathrm{mM} \mathrm{Na}$-acetate and $2 \mathrm{mM} \mathrm{FeCl}_{2}$ (as a reducing agent) from sterile, anaerobic stock solutions. The medium for enumeration of nitrate-dependent Fe(II)-oxidizing bacteria was amended with $0.5 \mathrm{mM} \mathrm{Na}$-acetate, $5 \mathrm{mM} \mathrm{NO}_{3}^{-}$ and $10 \mathrm{mM} \mathrm{FeCl}_{2}$ from sterile anaerobic stock solutions.

Pressure tubes were inoculated with $1-\mathrm{ml}$ portions of the homogenized freshwater wetland sediment slurry. The tubes were then homogenized by vortexing, serially diluted, and incubated statically in the dark at $30^{\circ} \mathrm{C}$ for 10 weeks. Positive results for acetate-oxidizing nitrate reducers were determined checking for depletion of $\mathrm{NO}_{3}{ }^{-}$(to $<1 \mathrm{mM}$ ) by ion chromatography. Visual assessment of blackening of the medium, and formation of reddish-brown precipitates, was used to identify positive results for $\mathrm{Fe}(\mathrm{III})$ reducers and nitrate-dependent $\mathrm{Fe}$ (II) oxidizers respectively. MPN estimates were obtained using the Most Probable Number Calculator version 4.05 (@1996 Albert J. Klee, Risk Reduction Engineering Laboratory, United States Environmental Protection Agency, Cincinnati, Ohio, freeware available at http://www.epa.gov/ nerlcwww/other.htm).

\section{Enrichment culture experiment}

A PIPES-buffered (10 mM, pH 6.8) AGW medium was used for the wetland sediment enrichment culture experiment. The basal AGW contained $0.11 \mathrm{mM} \mathrm{MgCl}, 0.61 \mathrm{mM} \mathrm{CaCl}_{2}$ and $2 \mathrm{mM} \mathrm{NaHCO}_{3}$, and was supplemented with $1 \mathrm{mM} \mathrm{NaNO}_{3}$, $2 \mathrm{mM}$ Na-acetate, $0.5 \mathrm{mM} \mathrm{NH}_{4} \mathrm{Cl}, 0.05 \mathrm{mM} \mathrm{KH}_{2} \mathrm{PO}_{4}, 0.1 \times$ of previously described (Lovley and Phillips, 1988) vitamin and trace element solutions, and $50 \mathrm{mmol} \mathrm{I}^{-1}$ of synthetic 'high surface area' (approximately $200 \mathrm{~m}^{2} \mathrm{~g}^{-1}$ ) goethite. The synthetic goethite was synthesized by slow air oxidation of $\mathrm{FeCl}_{2}$ in $\mathrm{NaHCO}_{3}$ buffer (Schwertmann and Cornell, 1991), and its surface area was determined by multipoint $\mathrm{N}_{2}$ (BET) adsorption (Micromeritics Model Gemini). Triplicate bottles of medium were inoculated with $1 \%$ (vol:vol) of anaerobic sediment slurry immediately after collection and preparation as described above. Samples were collected over time for analysis of $\mathrm{NO}_{3}{ }^{-}, \mathrm{NO}_{2}{ }^{-}, \mathrm{NH}_{4}{ }^{+}$, acetate, $\mathrm{Fe}(\mathrm{II})$, total $\mathrm{Fe}$ and $16 \mathrm{~S}$ rDNA/rRNA. Once $\mathrm{NO}_{3}{ }^{-}$and $\mathrm{Fe}(\mathrm{III})$ reduction ceased, $\mathrm{NO}_{3}{ }^{-}$ ( $3 \mathrm{mM})$ was re-added to the enrichment cultures in an attempt to induce nitrate-dependent $\mathrm{Fe}$ (II) oxidation. Immediately prior to the $3 \mathrm{mM} \mathrm{NO}_{3}{ }^{-}$amendment, a $30-\mathrm{ml}$ subculture was removed from each culture bottle, transferred into a sterile, anaerobic $\left(\mathrm{N}_{2}: \mathrm{CO}_{2} ; 80: 20\right)$ serum bottles, and pasteurized $\left(80^{\circ} \mathrm{C} ; 15 \mathrm{~min}\right)$ to produce killed controls. Killed controls were amended with $\mathrm{NO}_{3}^{-}(3 \mathrm{mM})$ following pasteurization. Live and pasteurized cultures were incubated statically in the dark at $30^{\circ} \mathrm{C}$ and homogenized prior to sampling.

\section{Anaerobic Fe redox cycling by $\mathrm{G}$. metallireducens}

Geobacter metallireducens (a gift from D. R. Lovley, University of Massachusetts Amherst) was grown in $\mathrm{NaHCO}_{3}$ buffered medium (30 mM NaHCO $3,10 \mathrm{mM} \mathrm{NH}_{4} \mathrm{Cl}, 1 \mathrm{mM}$ $\mathrm{KH}_{2} \mathrm{PO}_{4}$ ) with acetate $(10 \mathrm{mM})$ as the electron donor and nitrate $(20 \mathrm{mM})$ as the electron acceptor. The growth medium was supplemented with $0.5 \mathrm{mM} \mathrm{Fe}$ (III)-citrate in order to provide the extra $\mathrm{Fe}$ required for sustained growth with nitrate as the electron acceptor (Senko and Stolz, 2001), as well as $1 \mathrm{mM}$ ascorbic acid to reduce the accumulation of $\mathrm{NO}_{2}^{-}$which can inhibit cell growth on nitrate (E. J. P. Phillips, US Geological Survey, pers. comm.). Cells were harvested by centrifugation $(7000 \mathrm{~g}, 10 \mathrm{~min})$ and washed twice with sterile, anaerobic $\mathrm{NaHCO}_{3}$ buffer. Triplicate $20-\mathrm{ml}$ bottles of the AGW medium described above were inoculated with approximately $10^{8}$ cells $\mathrm{ml}^{-1}$ of washed cells, and changes in $\mathrm{NO}_{3}^{-}, \mathrm{NO}_{2}^{-}$, $\mathrm{NH}_{4}{ }^{+}$, acetate, $\mathrm{Fe}(\mathrm{II})$ and total Fe were monitored over time. As in the case of the wetland sediment enrichment culture experiment, $\mathrm{NO}_{3}{ }^{-}$(approximately $1 \mathrm{mM}$ ) was added to the cultures once acetate was depleted and $\mathrm{Fe}(\mathrm{III})$ reduction had ceased.

\section{Chemical and spectroscopic analyses}

Samples for analyses of $\mathrm{Fe}(\mathrm{II})$ and total Fe were collected and centrifuged $(10000 \mathrm{~g})$ inside an anaerobic chamber, as previously described (Weber et al., 2001). The supernatant was withdrawn from the pellet and immediately analysed for aqueous Fe(II) using Ferrozine (Stookey, 1970). The pellet was resuspended in $0.5 \mathrm{M} \mathrm{HCl}$ and allowed to extract overnight. $\mathrm{Fe}(\mathrm{II})$ and total $\mathrm{Fe}$ in the extract were determined as described in Roden and Lovley (1993). The concentration of $0.5 \mathrm{M} \mathrm{HCl}$-extractable $\mathrm{Fe}(\mathrm{II})$ determined via pellet extractions, together with aqueous $\mathrm{Fe}$ (II) measurements, were summed to yield total $\mathrm{Fe}$ (II) concentrations (Weber et al., 2001). Samples for $\mathrm{NO}_{3}^{-}, \mathrm{NO}_{2}^{-}, \mathrm{NH}_{4}^{+}$and acetate were filtered through a 0.2- $\mu \mathrm{m}$ nylon filter immediately after collection and exposed to $\mathrm{O}_{2}$ in order to rapidly oxidize $\mathrm{Fe}(\mathrm{II})$ (Weber et al., 2001). The filtered samples were centrifuged and the supernatant withdrawn for $\mathrm{NO}_{3}{ }^{-}$and $\mathrm{NO}_{2}{ }^{-}$analyses. Samples collected for $\mathrm{NH}_{4}{ }^{+}$were filtered a second time prior to analysis. $\mathrm{NO}_{3}{ }^{-}$and acetate were determined by ion chromatography (IonPac $®$ AS14 analytical column, Dionex DX-100 system, Dionex, 
Sunnyvale, $\mathrm{CA}$ ). $\mathrm{NO}_{2}^{-}$and $\mathrm{NH}_{4}^{+}$concentrations were determined colorimetrically (Wetzel and Likens, 1991) with detection limits of $0.01 \mu \mathrm{M}$ and $1 \mu \mathrm{M}$ respectively.

Powder XRD and low-temperature (77K) Mössbauer spectra of (i) microbially reduced goethite and (ii) microbially reduced goethite subjected to nitrate-dependent oxidation, were obtained as described in Kukkadapu and colleagues (2001, 2004). An XRD pattern was also obtained for a nonbiologically transformed HSA goethite preparation similar (but not identical) to the material used for the enrichment culture experiment.

\section{Nucleic acid extraction and purification}

Samples for nucleic acid extraction were collected in sterile, diethyl pyrocarbonate (DEPC) treated polyethylene centrifuge tubes and maintained on ice until centrifugation. Collected samples were centrifuged $(10000 \mathrm{~g}, 20 \mathrm{~min})$ and washed once with $10 \mathrm{mM}$ RNase-free Tris Buffer (pH 7.8). The pellet was immediately frozen in liquid $\mathrm{N}_{2}$ and stored at $-80^{\circ} \mathrm{C}$ until extraction of nucleic acids.

Nucleic acids were extracted using a modified method of Zhou and colleagues (1996) by grinding in liquid $\mathrm{N}_{2}$, freezethawing and extended heating $\left(60^{\circ} \mathrm{C}\right)$ in a high-salt extraction buffer containing hexadecylmethylammonium bromide (CTAB) and sodium dodecyl sulfate (SDS). CTAB was heated to $60^{\circ} \mathrm{C}$ prior to being added to the extraction buffer. Following centrifugation $(6000 \mathrm{~g}, 10 \mathrm{~min})$, the supernatant was removed from the pellet and nucleic acids were extracted in phenol:chloroform (1:1; vol:vol), followed by an additional chloroform extraction. Nucleic acids were precipitated in isopropanol, centrifuged (9000 g, $20 \mathrm{~min}$ ), and resuspended in RNase-free Tris-EDTA (TE) buffer. The nucleic acid extracts were divided into two equal volumes and stored at $-80^{\circ} \mathrm{C}$ until DNA and RNA purification. All materials and solutions used during the nucleic acid extraction process were treated with DEPC prior to use, with the exception of solutions containing Tris which were prepared in DEPC-treated (denoted as RNase-free) deionized water.

Nucleic acid extracts used for amplification of 16S rDNA were purified by gel filtration using Sepharose CL-4B columns as described by Jackson et al. (Jackson et al., 1997), precipitated with $\mathrm{NaCl}(0.2 \mathrm{M})$ in absolute ethanol overnight, and resuspended in TE buffer. DNA samples were stored at $-80^{\circ} \mathrm{C}$. Nucleic acid extracts dedicated to RT-PCR amplification of $16 \mathrm{~S}$ rRNA were purified by gel filtration using DEPCtreated Sephadex G-75 (Moran et al., 1993), precipitated with RNase-free Na-Acetate (0.3 M) in absolute ethanol overnight and resuspended in RNase-free TE buffer. DNA was removed from RNA by treatment with DNase I (RNase-free; Roche Diagnostics Corporation) followed by a phenol:chloroform (1:1; vol:vol) extraction. RNA was concentrated by precipitating with RNase-free Na-Acetate $(0.3 \mathrm{M})$ in absolute ethanol overnight and resuspended in RNase-free TE buffer. RNA extracts were stored at $-80^{\circ} \mathrm{C}$.

\section{Denaturing gradient gel electrophoresis}

A fragment of the variable V3 region of 16S rDNA corresponding to positions 341-907 in Escherichia coli was PCRamplified (Touchdown PCR) using the primers denoted as
341F, 5'-CCTACGGGAGGCAGCAG-3' and 907R, 5'-CCGTC AATTCCTTTRAGTTT-3' with a GC-Clamp added to $5^{\prime}$ end of forward primer: 5'CGCCCGCCGCGCGCGGCGGGCGGG GCGGGGGCACGGGGGG-3' as described by Muyzer and colleagues (1995). Within the Domain Bacteria, these primers are universally conserved (Medlin et al., 1988) and have thus been used to evaluate bacterial diversity in environmental samples (Muyzer et al., 1993; Muyzer and Ramsing, 1995) as well as the diversity of anaerobic Fe(II)-oxidizing bacteria (Buchholz-Cleven et al., 1997; Straub and BuchholzCleven, 1998). Products from 10 replicate PCR amplifications were combined, extracted in phenol:chloroform (1:1: vol:vol), precipitated with $\mathrm{NaCl}(0.2 \mathrm{M})$ in absolute ethanol overnight, and resuspended in TE buffer. Negative control PCR amplifications (no DNA added to reaction mix) were routinely conducted.

Reverse transcription of 16S rRNA was performed using SUPERSCRIPTTM II RNase $\mathrm{H}^{-}$Reverse Transcriptase (Gib$\operatorname{coBRL}^{\circledR}$ ) as specified by the manufacturer, with $907 \mathrm{R}$ serving as the reverse primer. The resulting cDNA was PCRamplified as described above. Negative reverse transcriptase reactions (reverse transcriptase absent from reaction mix) were routinely conducted and subsequently PCR-amplified as described above.

Denaturing gradient gel electrophoresis was conducted using a $6 \%$ acrylamide gel containing a $28-56 \%$ denaturing gradient (Muyzer and Ramsing, 1995). Polymerase chain reaction products of $16 \mathrm{~S}$ rDNA and reverse transcribed $16 \mathrm{~S}$ rRNA were applied directly to a $6 \%$ acrylamide gel in $0.5 \times$ TAE buffer. The gel was electrophoresed at $60^{\circ} \mathrm{C}$ at $200 \mathrm{~V}$ for 6 h using a Bio-Rad D Gene ${ }^{\mathrm{TM}}$ System (Bio-Rad Laboratories, Hercules, CA) (Muyzer et al., 1993). After electrophoresis, the gel was stained with ethidium bromide $\left(0.5 \mathrm{mg} \mathrm{l}^{-1}\right)$ for 15 min and rinsed with deionized $\mathrm{H}_{2} \mathrm{O}$ for 10 min prior to UV transillumination. Gel images were captured digitally.

Band intensity on DGGE gels was used to infer the relative abundance and metabolic activity of microorganisms present at different times during the enrichment culture experiment. This approach is based on the assumption that 16S rDNA abundance is directly related to density of the corresponding organism in the sample (Muyzer et al., 1993; Bruggemann et al., 2000), and that metabolically active cells possess greater 16S rRNA content than non-active cells (Kemp et al., 1993). It is recognized, however, that correlation of metabolic activity with $16 \mathrm{~S}$ rRNA content must be done with caution as regulation of metabolic activity and rRNA content may differ among various bacterial species (Wagner, 1994). In addition, the potential for inherent biases in PCR-based detection/ quantification strategies is well recognized (VonWintzingerode et al., 1997). Hence, changes in DGGE-banding patterns are interpreted as a first approximation of change in microbial community structure and metabolic activity in the enrichment culture samples.

\section{Clone libraries}

Amplification products for construction of $16 \mathrm{~S}$ rDNA clone libraries were generated with primers corresponding the positions 8F (5'-AGAGTTTGATCCTGGCTCAG-3'), and 907R (described above) in E. coli. Polymerase chain reaction products were purified using QIAquick PCR Purification Kit 
(QIAGEN \#28106) according to manufacturer's instructions and stored at $-20^{\circ} \mathrm{C}$. The $\mathrm{pGem} \AA-\mathrm{T}$ vector System (Promega \#A3600) was used according to manufacturer's instructions, with Top10 competent $E$. coli cells from Invitrogen, to generate clone libraries from PCR-amplified 16S rDNA from samples collected at days $0,1.5,9$ and 36 of the enrichment culture experiment. Between 90 and 100 clones were picked from each sample transformation. Vector primers M13F1 and M13R1 were used to amplify cloned sequences. Sequences were concentrated by precipitation in $95 \%$ ethanol and $\mathrm{NaCl}$ (200 mM) overnight at $-20^{\circ} \mathrm{C}$ and resuspended, in TA buffer (10 mM, pH 7.6). Concentrated DNA was purified by electrophoresis using a low melt agarose gel $(1.5 \%)$ in TAE running buffer. Bands in the gel were cut out, frozen overnight, and spun down at $10000 \mathrm{~g}$ for $10 \mathrm{~min}$. Supernatants were collected and used for sequencing. Clone sequences $(44,58$, 53 and 62 for days $0,1.5,9$ and 36 , respectively) were obtained commercially from Macrogen (Seoul, South Korea) using T7F and SP6R primers. Each sequence was analysed by means of GenBank using BLAST (Altschul et al., 1997) as well as the Ribosomal Database Project - II (Cole et al., 2003) in order to identify the closest relative. Sequences which were identified as chimeric were discarded. A value of $95 \% 16 \mathrm{~S}$ rDNA sequence identity was established as a conservative cut-off for assignment of genus-level phylogenetic affiliation (Gillis et al., 2001). The final sets of sequences have been submitted to GenBank (Accession numbers DQ110012-DQ110129).

\section{Acknowledgements}

This research was supported by Grant DE-FG02-97ER62482 from the US Department of Energy, Natural and Accelerated Bioremediation Program. X-ray diffraction and Mössbauer analyses were performed at W.R. Wiley Environmental and Molecular Sciences Laboratory, a national user facility sponsored by US Department of Energy's Office (DOE) Biological and Environmental Research and located at Pacific Northwest National Laboratory (PNNL). PNNL is operated by the DOE by Battelle.

\section{References}

Achtnich, C., Bak, F., and Conrad, R. (1995) Competition for electron donors among nitrate reducers, ferric iron reducers, sulfate reducers, and methanogens in anoxic paddy soil. Biol Fert Soils 19: 65-72.

Altschul, S.F., Madden, T.L., Schaffer, A.A., Zhang, J.H., Zhang, Z., Miller, W., and Lipman, D.J. (1997) Gapped BLAST and PSI-BLAST: a new generation of protein database search programs. Nucleic Acids Res 25: 3389-3402.

Benz, M., Brune, A., and Schink, B. (1998) Anaerobic and aerobic oxidation of ferrous iron at neutral $\mathrm{pH}$ by chemoheterotrophic nitrate-reducing bacteria. Arch Microbiol 169: 159-165.

Brock, T.D., and Gustafson, J. (1972) Sulfolobus: a new genus of sulfur-oxidizing bacteria living at low $\mathrm{pH}$ and high temperature. Arch Microbiol 84: 54-68.

Bruce, R.A., Achenback, L.A., and Coates, J.D. (1999) Reduction of (per) chlorate by a novel organism isolated from paper mill waste. Environ Microbiol 1: 319-329.
Bruggemann, J., Stephen, J.R., Chang, Y.J., Macnaughton, S.J., Kowalchuk, G.A., Kline, E., and White, D.C. (2000) Competitive PCR-DGGE analysis of bacterial mixtures: an internal standard and an appraisal of template enumeration accuracy. J Microbiol Methods 40: 111-123.

Buchholz-Cleven, B.E.E., Rattunde, B., and Straub, K.L. (1997) Screening for genetic diversity of isolates of anaerobic Fe(III) -oxidizing bacteria using DGGE and whole-cell hybridization. Syst Appl Microbiol 20: 301-309.

Caldwell, M.E., Tanner, R.S., and Suflita, J.M. (1999) Microbial metabolism of benzene and the oxidation of ferrous iron under anaerobic conditions: implications for bioremediation. Anaerobe 5: 595-603.

Chapelle, F.H. (2001) Ground-water Microbiology and Geochemistry. New York, NY, USA: John Wiley \& Sons.

Chaudhuri, S.K., Lack, J.G., and Coates, J.D. (2001) Biogenic magnetite formation through anaerobic biooxidation of Fe(II). Appl Environ Microbiol 67: 2844-2848.

Coates, J.D., Phillips, E.J.P., Lonergan, D.J., Jenter, H., and Lovley, D.R. (1996) Isolation of Geobacter species from a variety of sedimentary environments. Appl Environ Microbiol 62: 1531-1536.

Coates, J.D., Chakraborty, R., Lack, J., O'Connor, S.M., Cole, K.A., Bender, K.S., and Achenbach, L.A. (2001) Anaerobic benzene oxidation coupled to nitrate reduction in pure culture by two novel organisms. Nature 411: 10391043.

Cole, J.R., Chai, B., Marsh, T.L., Farris, R.J., Wang, Q., Kulam, S.A., et al. (2003) The Ribosomal Database Project (RDP-II): previewing a new autoaligner that allows regular updates and the new prokaryotic taxonomy. Nucleic Acids Res 31: 442-443.

Cooper, D.C., Picardal, F., Rivera, J., and Talbot, C. (2000) Zinc immobilization and magnetite formation via ferric oxide reduction by Shewanella putrefaciens 200. Environ Sci Technol 34: 100-106.

Cooper, D.A., Picardal, F.W., Schimmelmann, A., and Colby, A.J. (2003) Chemical and biological interactions during nitrate and goethite reduction by Shewanella putrefaciens 200. Appl Environ Microbiol 69: 3517-3525.

Cornell, R.M., and Schwertmann, U. (1996) The Iron Oxides. New York, NY, USA: VCH.

Cummings, D.E., Jr, Spring, S., and Rosenzweig, R.F. (1999) Ferribacterium limneticum, gen. nov., sp. nov., an Fe(III)reducing microorganism isolated from mining-impacted freshwater lake sediments. Arch Microbiol 171: 183-188.

Davison, W. (1993) Iron and manganese in lakes. Earth-Sci Rev 34: 119-163.

Davison, W., and Seed, G. (1983) The kinetics of the oxidation of ferrous iron in synthetic and natural waters. Geochim Cosmochim Acta 47: 67-79.

DiChristina, T.J. (1992) Effects of nitrate on dissimilatory iron reduction by Shewanella putrefaciens 200. J Bacteriol 174: 1891-1896.

Emerson, D. (2000) Microbial oxidation of Fe(II) and Mn(II) at circumneutral $\mathrm{pH}$. In Environmental Metal-Microbe Interactions. Lovley, D.R. (ed.). Washington, DC, USA: American Society for Microbiology Press, pp. 31-52.

Emerson, D., and Weiss, J.V. (2004) Bacterial iron oxidation in circumneutral freshwater habitats: findings from the field and the laboratory. Geomicrobiol J 21: 405-414. 
Finneran, K.T., Housewright, M.E., and Lovley, D.R. (2002) Multiple influences of nitrate on uranium solubility during bioremediation of uranium-contaminated subsurface sediments. Environ Microbiol 4: 510-516.

Gillis, M., Vandamme, P., DeVos, P., Swings, J., and Kersters, K. (2001) Polyphasic taxonomy. In Bergey's Manual of Systematic Bacteriology. Boone, D.R., and Castenholz, R.W. (eds). New York, NY, USA: Springer, pp. 43-48.

Hansen, H.C.B., Koch, C.B., Nancke-Krogh, H., Borggaard, O.K., and Sorensen, J. (1996) Abiotic nitrate reduction to ammonium: key role of green rust. Environ Sci Technol 30: 2053-2056.

Hansen, H.C.B., Guldberg, S., Erbs, M., and Koch, C.B. (2001) Kinetics of nitrate reduction by green rusts - effects of interlayer anion and $\mathrm{Fe}(\mathrm{II}): \mathrm{Fe}(\mathrm{III})$ ratio. Appl Clay Sci 18: 81-91.

Hauck, S., Benz, M., Brune, A., and B.S. (2001) Ferrous iron oxidation by denitrifying bacteria in profundal sediments of a deep lake (Lake Constance). FEMS Microbiol Ecol 37: 127-134.

Jackson, C.R., Harper, J.P., Willoughby, D., Roden, E.E., and Churchill, P.F. (1997) A simple, efficient method for the separation of humic substances and DNA from environmental samples. Appl Environ Microbiol 63: 49934995.

Johnson, D.B., McGinness, S., and Ghauri, M.A. (1993) Biogeochemical cycling of iron and sulfur in leaching environments. FEMS Microbiol Rev 11: 63-70.

Jones, J.G., Gardener, S., and Simon, B.B. (1983) Bacterial reduction of ferric iron in a stratified eutrophic lake. J Gen Microbiol 129: 131-139.

Kemp, P.R., Lee, S., and Laroche, J. (1993) Estimating the growth rate of slowly growing marine bacteria from RNA content. Appl Environ Microbiol 59: 2594-2601.

Kluber, H.D., and Conrad, R. (1998) Effects of nitrate, nitrite, $\mathrm{NO}$, and $\mathrm{N} 2 \mathrm{O}$ on methanogenesis and other redox processes in anoxic rice soil. FEMS Microbiol Ecol 25: 301318.

Kukkadapu, R.K., Zachara, J.M., Smith, S.C., Fredrickson, J.K., and Liu, C. (2001) Dissimilatory bacterial reduction of Al-substituted goethite in subsurface sediments. Geochim Cosmochim Acta 65: 2913-2924.

Kukkadapu, R.K., Zachara, J.M., Fredrickson, J.K., and Kennedy, D.W. (2004) Biotransformation of two-line silicaferrihydrite by a dissimilatory $\mathrm{Fe}(\mathrm{III})$-reducing bacterium: formation of carbonate green rust in the presence of phosphate. Geochim Cosmochim Acta 68: 2799-2814.

Lack, J.G., Chaudhuri, S.K., Kelly, S.D., Kemner, K.M., O'Connor, S.M., and Coates, J.D. (2002) Immobilization of radionuclides and heavy metals through anaerobic biooxidation of Fe(II). Appl Environ Microbiol 68: 2704-2710.

Lovley, D.R. (1991) Dissimilatory Fe(III) and Mn (IV) reduction. Microbiol Rev 55: 259-287.

Lovley, D.R. (2000) Fe(III) and Mn(IV) reduction. In Environmental Metal-Microbe Interactions. Lovley, D.R. (ed.). Washington, DC, USA: American Society for Microbiology Press, pp. 3-30.

Lovley, D.R. (2002) Fe(III)- and Mn(IV)-reducing prokaryotes. In The Prokaryotes. Stackebrandt, E. (ed.). NY, USA: Springer-Verlag [www document]. URL http://et.springerny.com:8080/prokPUB/index.htm.
Lovley, D.R., and Phillips, E.J.P. (1988) Novel mode of microbial energy metabolism: organic carbon oxidation coupled to dissimilatory reduction of iron or manganese. Appl Environ Microbiol 54: 1472-1480.

Lovley, D.R., and Anderson, R.T. (2000) The influence of dissimilatory metal reduction on the fate of organic and metal contaminants in the subsurface. $J$ Hydrol 8: 77-88.

Mahne, I., and Tiedje, J. (1995) Criteria and methodology for identifying respiratory denitrifiers. Appl Environ Microbiol 61: 1110-1115.

Medlin, L., Elwood, H.J., Stickel, S., and Sogin, M.L. (1988) The characterization of enzymatically amplified eukaryotic 16S-like rRNA coding regions. Gene 71: 491-499.

Millero, F.J., Sotolongo, S., and Izaguirre, M. (1987) The oxidation kinetics of $\mathrm{Fe}(\mathrm{II})$ in seawater. Geochim Cosmochim Acta 51: 793-801.

Moran, M.A., Torsvik, V.L., Torsvik, T., and Hodson, R.E. (1993) Direct extraction and purification of rRNA for ecological studies. Appl Environ Microbiol 59: 915-918.

Muyzer, G., and Ramsing, N.B. (1995) Molecular methods to study the organization of microbial communities. Water Sci Technol 32: 1-9.

Muyzer, G., Dewaal, E.C., and Uitterlinden, A.G. (1993) Profiling of complex microbial populations by denaturing gradient gel electrophoresis analysis of polymerase chain reaction-amplified genes coding for 16S rRNA. Appl Environ Microbiol 59: 695-700.

Muyzer, G., Hottentrager, S., Teske, A., and Wawer, C. (1995) Denaturing gel electrophoresis of PCR-amplified 16S rDNA - a new molecular approach to analyse the genetic diversity of microbial communities. In Molecular Microbial Ecology Manual. Akkermans, D.L., vanElsas, J.D., and deBruijn, F.J. (eds). Dordrecht, the Netherlands: Kluwer, pp. 3.4.4.1-3.4.4.22.

Nielsen, J.L., and Nielsen, P.H. (1998a) Microbial nitratedependent oxidation of ferrous iron in activated sludge. Environ Sci Technol 32: 3556-3561.

Nielsen, J.L., and Nielsen, P.H. (1998b) Microbial Fe(II)oxidation by nitrate in activated sludge. Water Sci Technol 37: 406-406.

Obuekwe, C.O., Westlake, D.W.S., and Cook, F.D. (1981) Effect of nitrate on reduction of ferric iron by a bacterium isolated from crude oil. Can J Microbiol 27: 692-697.

Ratering, S., and Schnell, S. (2000) Nitrate-dependent iron (II) oxidation in paddy soil. Environ Microbiol 3: 100109.

Roden, E.E., and Lovley, D.R. (1993) Evaluation of ${ }^{55} \mathrm{Fe}$ as a tracer of $\mathrm{Fe}(\mathrm{III})$ reduction in aquatic sediments. Geomicrobiol J 11: 49-56.

Roden, E.E., and Wetzel, R.G. (1996) Organic carbon oxidation and suppression of methane production by microbial $\mathrm{Fe}$ (III) oxide reduction in vegetated and unvegetated freshwater wetland sediments. Limnol Oceanogr 41: 17331748.

Roden, E.E., and Urrutia, M.M. (2002) Influence of biogenic $\mathrm{Fe}$ (II) on bacterial reduction of crystalline $\mathrm{Fe}(\mathrm{III})$ oxides. Geomicrobiol J 19: 209-251.

Roden, E.E., Sobolev, D., Glazer, B., and Luther, G.W. (2004) Potential for microscale bacterial Fe redox cycling at the aerobic-anaerobic interface. Geomicrobiol $J$ 21: 379-391. 
Schwertmann, U., and Cornell, R.M. (1991) Iron Oxides in the Laboratory. New York, NY, USA: Weinheim.

Senko, J.M., and Stolz, J.F. (2001) Evidence for irondependent nitrate respiration in the dissimilatory ironreducing bacterium Geobacter metallireducens. Appl Environ Microbiol 67: 3750-3752.

Senn, D.B., and Hemond, H.F. (2002) Nitrate controls on iron and aresenic in an urban lake. Science 296: 23732376.

Shelobolina, E.S., Gaw-VanPraagh, C., and Lovley, D.R. (2003) Use of ferric and ferrous iron containing minerals for respiration by Desulfitobacterium frappieri. Geomicrobiol J 20: 143-156.

Singer, P.C., and Stumm, W. (1972) Acid mine drainage the rate limiting step. Science 167: 1121-1123.

Sorensen, J. (1982) Reduction of ferric iron in anaerobic, marine sediment and interaction with reduction of nitrate and sulfate. Appl Environ Microbiol 43: 319-324.

Stookey, L.L. (1970) Ferrozine - a new spectrophotometric reagent for iron. Anal Chem 42: 779-781.

Straub, K.L., Benz, M., Schink, B., and Widdel, F. (1996) Anaerobic, nitrate-dependent microbial oxidation of ferrous iron. Appl Environ Microbiol 62: 1458-1460.

Straub, K.L., and Buchholz-Cleven, B.E.E. (1998) Enumeration and detection of anaerobic ferrous-iron oxidizing, nitrate-reducing bacteria from diverse European sediments. Appl Environ Microbiol 64: 4846-4856.

Straub, K.L., Benz, M., and Schink, B. (2001) Iron metabolism in anoxic environments at near neutral $\mathrm{pH}$. FEMS Microbiol Ecol 34: 181-186.

Straub, K.L., Schonhuber, W.A., Buchholz-Cleven, B.E.E., and Schink, B. (2004) Diversity of ferrous iron-oxidizing, nitrate-reducing bacteria and their involvement in oxygenindependent iron cycling. Geomicrobiol J 21: 371-378.

Stumm, W., and Sulzberger, B. (1992) The cycling of iron in natural environments: considerations based on laboratory studies of heterogeneous redox processes. Geochim Cosmochim Acta 56: 3233-3257.

VanBreemen, N. (1988) Long-term chemical, mineralogical and morphological effects of iron-redox processes in periodically flooded soils. In Iron in Soils and Clay Minerals. Stucki, J.W., Goodman, B.A., and Schwertmann, U. (eds) Boston: D. Reidel Publishing, pp. 811-823.

VonWintzingerode, F., Goebel, U.B., and Stackebrandt, E. (1997) Determination of microbial diversity in environmental samples: pitfalls of PCR-based rRNA analysis. FEMS Microbiol Rev 21: 213-229.

Wagner, R. (1994) The regulation of ribosomal RNA synthesis and bacterial cell growth. Arch Microbiol 161: 100109.

Weber, K.A. (2002) Microbial coupling between nitrogen and iron cycles. Potential implications for nitrate and iron biogeochemistry and metal mobility in sedimentary environments. PhD Dissertation. University of Alabama, Tuscaloosa, AL, USA.

Weber, K.A., Picardal, F.W., and Roden, E.E. (2001) Microbially-catalyzed nitrate-dependent oxidation of biogenic solid-phase $\mathrm{Fe}(\mathrm{II})$ compounds. Environ Sci Technol 35: 1644-1650.

Wetzel, R.G., and Likens, G.E. (1991) Limnological Analyses. New York, NY, USA: Springer-Verlag.

Woomer, P.L. (1994) Most probable number counts. In Methods of Soil Analysis Part 2 - Microbiological and Biochemical Properties. Bigham, J.M. (ed.). Madison, WI, USA: Soil Science Society of America, pp. 59-79.

Zachara, J.M., Fredrickson, J.K., Smith, S.C., and Gassman, P.L. (2001) Solubilization of Fe(III) oxide-bound trace metals by a dissimilatory Fe(III) reducing bacterium. Geochim Cosmochim Acta 65: 75-93.

Zhou, J., Bruns, M.A., and Tiedje, J.M. (1996) DNA recovery from soils of diverse composition. Appl Environ Microbiol 62: 316-322. 